\title{
Hypoxia Has a Lasting Effect on Fast-Startle Behavior of the Tropical Fish Haemulon plumieri
}

\author{
MAYRA A. SÁNCHEZ-GARCÍA ${ }^{1,2, *}$, STEVEN J. ZOTTOLI ${ }^{2,3}$, AND LORETTA M. ROBERSON $^{2}$ \\ ${ }^{1}$ University of Puerto Rico Río Piedras, P.O. Box 70377, San Juan, Puerto Rico 00936-8377; \\ ${ }^{2}$ Marine Biological Laboratory, 7 MBL Street, Woods Hole, Massachusetts 02543; and ${ }^{3}$ Department of Biology, \\ Williams College, 59 Lab Campus Drive, Williamstown, Masssachusetts 01267
}

\begin{abstract}
Anthropogenic activities and climate change have resulted in an increase of hypoxic conditions in nearshore ecosystems worldwide. Depending on the persistence of a hypoxic event, the survival of aquatic animals can be compromised. Temperate fish exposed to hypoxia display a reduction in the probability of eliciting startle responses thought to be important for escape from predation. Here we examine the effect of hypoxia on the probability of eliciting fast-startle responses (fast-starts) of a tropical fish, the white grunt (Haemulon plumieri), and whether hypoxia has a prolonged impact on behavior once the fish are returned to normoxic conditions. White grunts collected from the San Juan Bay Estuary in Puerto Rico were exposed to an oxygen concentration of $2.5 \mathrm{mg} \mathrm{L}^{-1}$ (40\% dissolved oxygen). We found a significant reduction in auditoryevoked fast-starts that lasted for at least 24 hours after fish were returned to normoxic conditions. Accessibility to the neuronal networks that underlie startle responses was an important motivator for this study. Mauthner cells are identifiable neurons found in most fish and amphibians, and these cells are known to initiate fast-starts in teleost fishes. The assumption that most of the short-latency responses in this study are Mauthner cell initiated provided the impetus to characterize the white grunt Mauthner cell. The identification of the cell provides a first step in understanding how low oxygen levels may impact a single cell and its circuit and the behavior it initiates.
\end{abstract}

Received 2 August 2018; Accepted 7 May 2019; Published online 16 July 2019.

* To whom correspondence should be addressed. Email: mayra.a.sanchezg@ gmail.com.

Abbreviations: ASR, aquatic surface respiration; DO, dissolved oxygen; EHP, extrinsic hyperpolarizing potential; M-cells, Mauthner cells; NEP, National Estuary Program; $P_{\text {crit }}$, critical oxygen level; PHP, passive hyperpolarizing potential; SJBE, San Juan Bay Estuary.

\section{Introduction}

Nearshore ecosystems provide essential refuge and nursery habitats for many animals, including fishes (Dennis, 1992; Laegdsgaard and Johnson, 1995; Nagelkerken et al., 2000; Beck et al., 2001). About $50 \%$ of the world's population now lives in coastal zones (UNEP and UN-Habitat, 2005). As a result, the water quality of these ecosystems is degraded by the discharge of sediments; by the increased eutrophication resulting from agricultural fertilizers, sewage, and animal wastes (Smith, 2003); and by the increased presence of pollutants, all of which threaten marine biota and human health (Ellison and Farnsworth, 1996; Kennish, 2002; Ahn et al., 2005; Diaz and Rosenberg, 2008; Diaz and Breitburg, 2009; Martinuzzi et al., 2009; Rees et al., 2012). One major stressor for organisms living in nearshore ecosystems is the reduction of dissolved oxygen (DO) in the water column. Although oxygen concentration changes naturally as a result of a number of factors, including primary productivity, tidal flow, and seasonally variant fresh water runoff (Paerl et al., 1998; Weis et al., 2011), anthropogenic activity and climate change have increased the frequency and prevalence of hypoxic events (Rosenberg, 1995; Diaz, 2001; Diaz and Breitburg, 2009; Keeling, 2010; Van Meter et al., 2018). High water temperatures accelerate organic decomposition and deplete oxygen content, thereby making tropical ecosystems more susceptible to hypoxic conditions (Chapman and McKenzie, 2009). Depending on the persistence of a hypoxic event, the survival of aquatic animals can be compromised (Diaz and Rosenberg, 1995; Shimps et al., 2005; Altieri et al., 2017).

A variety of temperate fish species are sensitive to hypoxia (Wannamaker and Rice, 2000; Lefrançois et al., 2005, 2009; Lefrançois and Domenici, 2006). European sea bass, Dicentrarchus labrax, and the golden grey mullet, Liza aurata, display a reduction in the probability of eliciting startle responses 
(i.e., reduced responsiveness) under hypoxic conditions (Lefrançois et al., 2005; Lefrançois and Domenici, 2006). We wondered whether a comparable reduced responsiveness occurs in a tropical fish, the white grunt (Haemulon plumieri), and whether exposure to hypoxia has a prolonged impact on behavior once the fish are returned to normoxic conditions. We found that hypoxia lowers the probability of fast-startle responses (faststarts) elicited by an abrupt auditory stimulus and that the reduction lasts for at least 24 hours after the return to normoxic conditions. Since fast-start responses are thought to be important in escape from predation (Eaton and Hackett, 1984; Canfield and Rose, 1993; Eaton et al., 2001; however see Catania, 2009), these results imply that fish exposed to hypoxia may be more vulnerable to predation, even after they return to normoxic conditions.

Two types of fast-starts (C-type, responses where initial movement is in the form of a C-shaped body bend, and S-type, responses where the initial movement is in the form of an S-shaped body bend) have been described based on the initial body shape of the fish (Hale, 2002; Schriefer and Hale, 2004; Liu et al., 2012; Liu and Hale, 2017). Mauthner cells (M-cells), identifiable neurons found in most fish and amphibians, are known to initiate C-type fast-starts in response to acoustic stimuli in adult goldfish (Zottoli, 1977; Eaton et al., 1981). The accessibility of the M-cell network was an important motivator for this study (Fetcho and Faber, 1988; Faber et al., 1989; Eaton et al., 2001; see Discussion). Our assumption that most of the short-latency responses in this study are M-cell initiated provided the impetus to characterize morphological and electrophysiological features of the white grunt M-cell. The identification of the cell provides a first step in understanding how low oxygen levels may impact a single cell and its circuit, the behavior it initiates, and, ultimately, how changes in the behavior may affect population and ecosystem levels.

\section{Materials and Methods}

\section{Collection site, fish collection, and maintenance}

Condado Lagoon is one of five lagoons in the tropical San Juan Bay Estuary (SJBE) in San Juan, Puerto Rico, with a legacy of uncontrolled urban expansion and pollution that has threatened the health of this ecosystem for decades (Fig. 1; Kennedy et al., 1996; Webb and Gómez-Gómez, 1998). The SJBE, located within the San Juan metropolitan area, was designated by the U.S. Environmental Protection Agency National Estuary Program (NEP) as "an estuary of national importance" due to its ecological and commercial importance (Otero, 2011) and because it is the only tropical estuary within the NEP. Condado Lagoon is a nursery for many fish species, including the white grunt. This fish was chosen because it is an abundant tropical species (Courtenay, 1961; Darcy, 1983) and an important ecological, commercial, and recreational fish throughout its distribution from Virginia, USA, to Brazil (De Silva and Murphy, 2001). Additionally, this fish is used as a bio-indicator
A

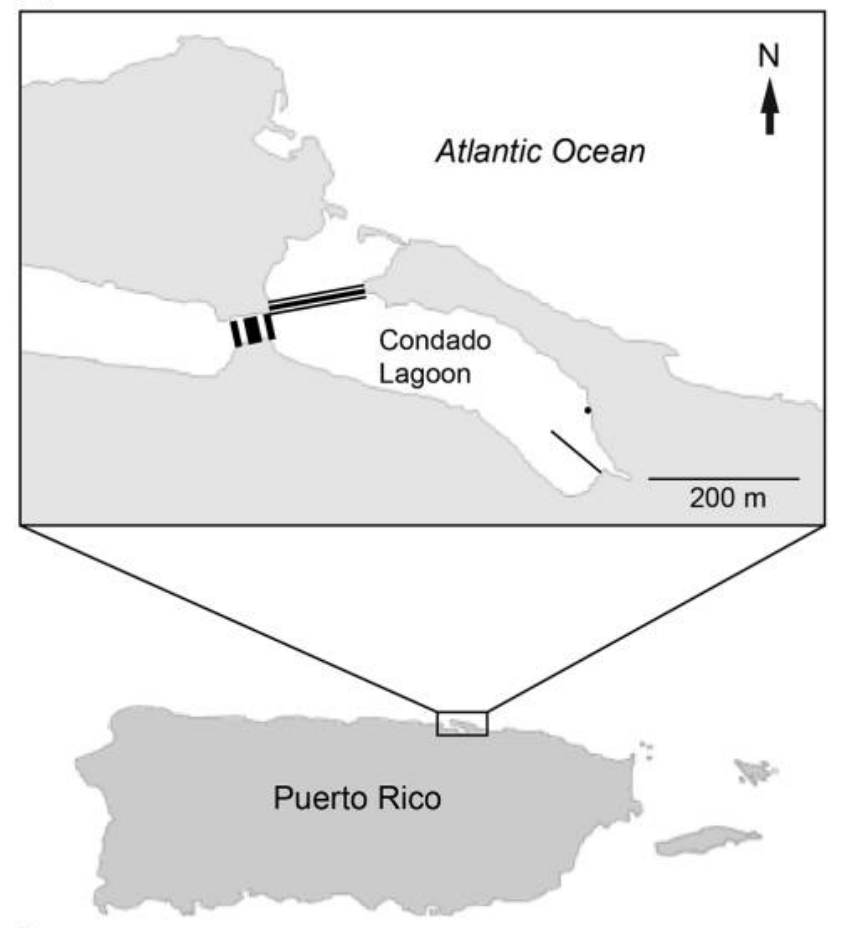

B

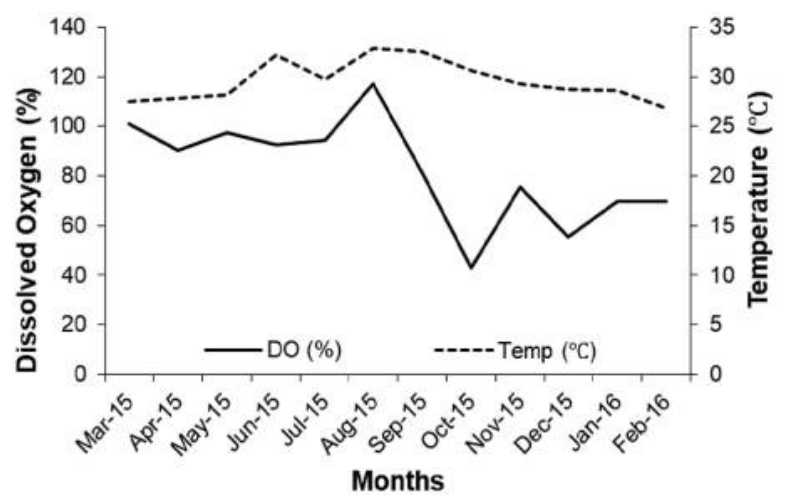

Figure 1. White grunt (Haemulon plumieri) collection site. (A) Condado Lagoon, Puerto Rico. The lagoon is connected to the Atlantic Ocean to the north and to the San Juan Bay by way of the San Antonio Channel to the west. Collection of $\mathrm{H}$. plumieri was done along a bridge that extends $100 \mathrm{~m}$ from the eastern shore (black line). The San Juan Bay Estuary Water Quality Monitoring program sampling site is indicated by a black dot. (B) Dissolved oxygen (DO) and temperatures in Condado Lagoon from March 2015 to February 2016. The graph shows percent dissolved oxygen (solid line) and water temperature $\left({ }^{\circ} \mathrm{C}\right.$; dashed line) during the study period.

for water quality by the Mesoamerican Barrier Reef System Synoptic Monitoring Program (Alpuche-Gual and Gold-Bouchot, 2008).

White grunts (Haemulon plumieri (Lacepède, 1801)), 8-11 cm in total length, were collected from March 2015 through February 2016 (collection permits R-VS-PVS15-SJ-00409-290814 and R-VS-PV15-SJ-00482-02092015) from a pier that extends about $100 \mathrm{~m}$ from the shore on the eastern side of the lagoon 
(Fig. 1A). We assumed that fish in this size range were juveniles because sexual maturity occurs at a standard length greater than $18 \mathrm{~cm}$ (Darcy, 1983; Palazón-Fernández, 2007). The depth of the collection site was about $1 \mathrm{~m}$, with average water temperatures in the range of $26.8-32.9{ }^{\circ} \mathrm{C}$, salinity between 28 and $44 \mathrm{ppt}$, and DO between 2.5 and $8.99 \mathrm{mg} \mathrm{L}^{-1}$ of air saturation (40\%-117\%) during the collection period (Fig. 1B; Table A1).

Fish were caught by cast net and transported in insulated buckets with constantly aerated water to the laboratory. Upon arrival, fish were transferred to 50-gallon holding tanks. The temperature $\left(28-31^{\circ} \mathrm{C}\right)$ and salinity $(35-38 \mathrm{ppt})$ of the holding tank seawater (Instant Ocean, Spectrum Brands, Blacksburg, VA) were maintained within the range of seawater at the collection site. The holding tanks were continuously aerated, and the oxygen level was maintained at $6.4 \mathrm{mg} \mathrm{L}^{-1}$ (100\% DO). Fish were exposed to an alternating light : dark cycle of $12 \mathrm{~h}: 12 \mathrm{~h}$. Water quality (i.e., salinity, $\mathrm{pH}$, and temperature) was monitored daily utilizing standard methods, and nitrite and nitrate levels were measured weekly. Fish were fed three times per week with raw squid or freeze-dried shrimp (Omega One, OmegaSea, Plainesville, OH). Fish were held for a minimum of three days prior to experimentation to ensure that they were free of infections and that they ate regularly. Fish were not fed for 24 hours prior to experimentation (Institutional Animal Care and Use Committee protocols 0081908-16-2013 and 01006-01-09-2015).

\section{Experimental setup and image analysis}

A circular plexiglass test tank $(27 \mathrm{~cm}$ inside diameter $\times$ $19.4 \mathrm{~cm}$ depth) was placed on top of a $15-\mathrm{cm}$ speaker (Tannoy Music Group, Coatbridge, United Kingdom) (Fig. 2). The tank was filled with salt water to a depth of $10 \mathrm{~cm}(6-\mathrm{L}$ total volume). The temperature in the test chamber was maintained between 27.5 and $31{ }^{\circ} \mathrm{C}$ to match the temperature at the collection site. Normoxic oxygen levels $\left(100 \% \mathrm{DO}=6.4 \mathrm{mg} \mathrm{L}^{-1}\right)$ were maintained by bubbling air into the water, and nitrogen gas was bubbled in the water to establish hypoxic conditions. Measurements of DO were made inside the test chamber with a ProODO probe (YSI, Yellow Springs, $\mathrm{OH}$ ) and of $\mathrm{pH}$ with a $\mathrm{pH} / \mathrm{CO}_{2}$ controller (Tunze 7074/2, Penzberg, Germany). The outside of the test tank was covered with an opaque film, and dark fabric was draped over the entire setup (Fig. 2A) to eliminate visual stimulation of the fish by experimenters. Preliminary experiments indicated that 1 cycle of a $100-\mathrm{Hz}$ signal consistently elicited startle responses, similar to stimuli used by others for goldfish ( 2 cycles of a $200-\mathrm{Hz}$ signal: Zottoli, 1977; 1 cycle of a 200-Hz signal: Preuss and Faber, 2003; 1 cycle of a 200-Hz signal: Mirjany et al., 2011). Our auditory stimulus was produced by a signal generator (Rag-101, Rek, Guangdong, China) in combination with an audio power amplifier (Radio Shack MPA-50, Tandy Corp., Fort Worth, TX). A high-speed camera (MotionXtra HG-XR Imaging System,

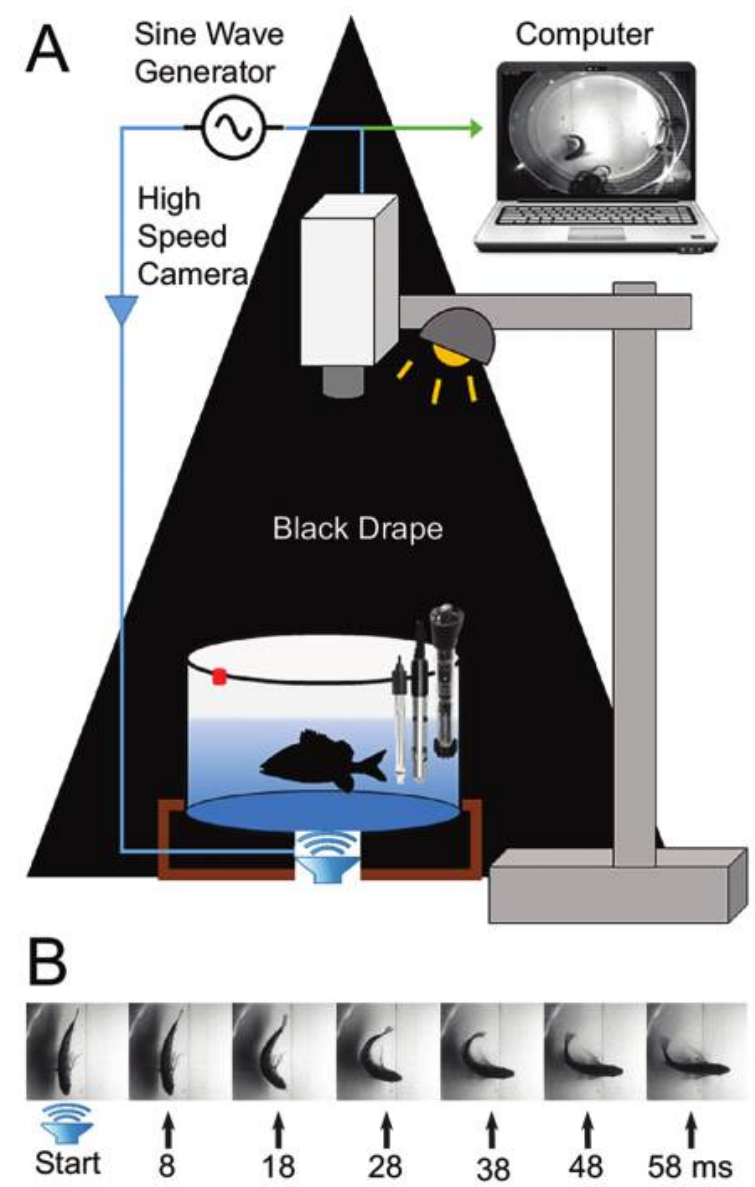

Figure 2. Schematic of the behavioral test arrangement. (A) Test tank setup (not drawn to scale). A white grunt (Haemulon plumieri) was placed in a test tank and after acclimation was stimulated with an abrupt sound stimulus consisting of 1 cycle of a $100-\mathrm{Hz}$ signal. The activation of the sound simultaneously triggered a high-speed camera (1000 fps) and an LED (square on tank). (B) A sequence of images of a fast-start response (C-start). The initial image denotes the onset ("Start") of the stimulus, followed by the first movement of the head $8 \mathrm{~ms}$ later. Subsequent images are spaced at 10-ms intervals.

DEL Imaging System, Cheshire, CT) positioned above the test chamber was used to record the response of the fish at 1000 frames per second, and 250 milliseconds of data (i.e., 250 frames) for each trial was saved for analysis. The camera was programmed to start filming prior to a stimulus, and we used an LED light on the side of the tank as an indicator of the onset of the stimulus (the LED turned on at the same time the sound stimulus was delivered).

The location of fish in the chamber prior to stimulation was recorded during each trial to determine whether position influenced the probability of eliciting a response. There was no correlation between tank position and whether a fast-start was elicited (for a subset of 9 experimental fish, Mann-Whitney test, $U=13, P=0.0514, n=216$ ). We were unable to determine the directionality of fast-starts because the stimulus was distributed over the entire base of the tank. 
The $\mathrm{pH}$ was measured from the end of normoxia acclimation until the end of hypoxic testing in nine fish (nos. 1-5 of Fig. 3) to determine whether $\mathrm{pH}$ changed as DO was reduced. There was no change in $\mathrm{pH}$ of the water for 4 fish, a decrease of 0.01 units for 2 fish, and a decrease of 0.02 units for 3 fish. We do not believe that these acidic shifts in $\mathrm{pH}$ affected our results.

\section{Startle response protocol}

Thirty fish were collected and divided into a control group $(n=12)$ and an experimental group $(n=18)$ to assess the effects of hypoxia on the probability of eliciting a fast-start and the latency of the response to an abrupt auditory stimulus. Each fish was placed in the experimental chamber; and after 30 minutes of acclimation to the chamber in normoxic conditions $\left(6.4 \mathrm{mg} \mathrm{L}^{-1}\right)$, it was stimulated for 6 consecutive soundtest trials (baseline normoxia) (Fig. 3). A three- to four-minute inter-trial interval was used for these and all subsequent soundtest trials. This interval did not result in habituation of control fish (see Results).

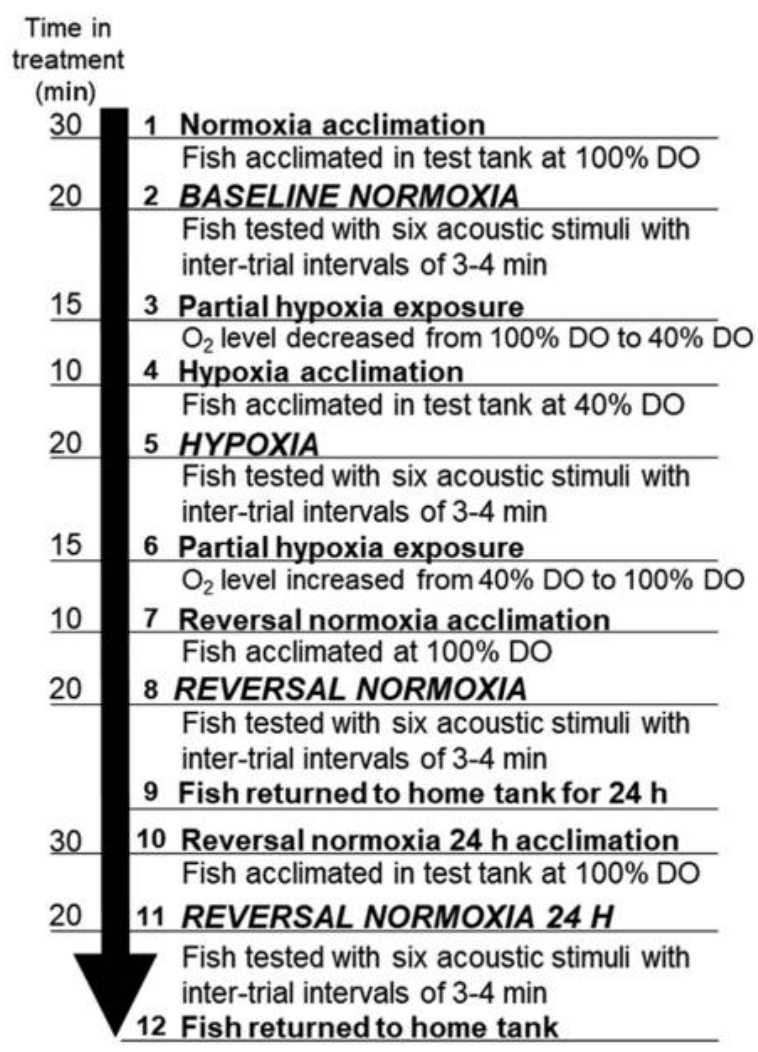

Figure 3. Experimental treatment protocol. Experimental treatment protocol with a timeline. White grunts (Haemulon plumieri) were tested at four intervals (2, baseline normoxia; 5 , hypoxia; 8 , reversal normoxia; 11 , reversal normoxia $24 \mathrm{~h}$ ). Control fish were subjected to the same timeline as experimental fish (nos. 1-9) but were maintained under normoxic conditions throughout all treatments (2, baseline normoxia; 8 , reversal normoxia). The same aeration sequence was used for controls, except that air was bubbled instead of nitrogen. DO, dissolved oxygen.
White grunts were exposed to a single hypoxic level of level of $2.5 \mathrm{mg} \mathrm{L}^{-1}$ (40\% DO) for the behavioral studies. This oxygen level was selected because (1) this level has been recorded in Condado Lagoon 3 times between 2013 and 2017, and a DO level of $42 \%$ was recorded during our study as shown in Figure $1 \mathrm{~B}$, and (2) it was the lowest concentration where fish equilibrium remained normal. Indeed, 3 fish exposed to a lower oxygen level (1.88 $\mathrm{mg} \mathrm{L}^{-1}$ [30\% DO]) lost equilibrium.

For experimental fish $(n=18)$, hypoxia was produced by bubbling nitrogen for $15 \mathrm{~min}$, bringing the oxygen level down to $2.5 \mathrm{mg} \mathrm{L}^{-1}(40 \% \mathrm{DO})$. Each fish was then acclimated at $2.5 \mathrm{mg} \mathrm{L}^{-1}$ for $10 \mathrm{~min}$ before sound stimulation. After 6 sound trials (Fig. 3, hypoxia), air was bubbled for $15 \mathrm{~min}$ to bring the DO concentration back up to $100 \%$ saturation, where it was held for $10 \mathrm{~min}$; and then each fish was tested with 6 more trials (Fig. 3, reversal normoxia). Fish spent about $30 \mathrm{~min}$ in oxygen levels of $2.5 \mathrm{mg} \mathrm{L}^{-1}$ (40\% DO) and $30 \mathrm{~min}$ in partial hypoxic conditions (i.e., shifts between treatments; nos. 3 and 6 of Fig. 3). After the baseline normoxia-hypoxia-reversal normoxia sequence, fish were returned to their home tank; and $24 \mathrm{~h}$ later, 12 of the 18 experimental fish were acclimated in normoxic treatment for $30 \mathrm{~min}$ and then tested with 6 sound trials (Fig. 3, reversal normoxia $24 \mathrm{~h}$ ). After the trials, fish were placed in their home tank and observed over three days to ensure that treatments did not adversely affect their equilibrium or their ability to feed, and then fish were returned to Condado Lagoon.

Control fish were subjected to the same intervals and treatment times as experimental fish but were maintained under normoxic treatment for all testing. The same aeration sequence was used, except that air was bubbled instead of nitrogen.

\section{Histological techniques}

Two white grunts were used for morphological characterization of M-cells. Fish were anesthetized in $0.03 \%$ ethylm-aminobenzoate (Sigma-Aldrich, St. Louis, MO) until respiration ceased. The heart was exposed, a cannula was placed through the ventricle into the bulbous arteriosus, and the cannula was secured by looping and tying suture thread around the junction. Fixative (4\% paraformaldehyde in phosphate buffer, $\mathrm{pH}$ 7.4) was then perfused through the circulatory system. The brains were removed and placed in fresh fixative overnight. The brains were dehydrated, cleared, embedded in paraffin, and sectioned in the transverse plane at $15 \mu \mathrm{m}$. Sections were stained with Morse's modification of Bodian's silver technique (see Zottoli et al., 2011), dehydrated, and coverslipped.

\section{Electrophysiological techniques}

Five white grunts were used for electrophysiological characterization of M-cells. Fish were initially anesthetized in $0.03 \%$ ethyl-m-aminobenzoate (Sigma-Aldrich) until respiration ceased. They were then placed in a holding chamber and secured between tapered stainless-steel rods whose tips were coated with 
topical anesthetic (20\% benzocaine in a water-soluble glycol base; Ultracare, Ultradent Products, South Jordan, UT). In the holding chamber, aerated seawater containing $0.012 \%$ of anesthetic was passed through the mouth and over the gills. The skin over the skull was then coated with local anesthetic (20\% benzocaine in a water-soluble glycol base; Ultracare). After 10 min the skull was removed to expose the hindbrain. Care was taken to avoid contact of the local anesthetic with the brain and spinal cord. Two hundred micrograms of pancuronium bromide (MP Biomedicals, Solon, $\mathrm{OH}$ ) was injected into the trunk musculature at the mid-body level about $1-2 \mathrm{~cm}$ ventral to the dorsal fin to block neuromuscular transmission. Once all operations had been performed and all exposed surfaces had been coated with local anesthetic, the fish were taken off of general anesthesia for physiological recordings. Local anesthetic was reapplied to exposed tissues during the experiment at 20-min intervals.

The dissection to expose the surface of the medulla oblongata is similar to that described for the sea robin (Zottoli et al., 2011). The hindbrain was exposed from the optic tecta to the rostral spinal cord. To expose the fourth ventricle and the surface of the medulla oblongata, a portion of the cerebellum was removed; and the remainder was displaced rostrally and held in place with Kimwipes (Kimberly-Clark, Irving, TX). The surface of the medulla oblongata was completely exposed by separating the overlying tissue at the midline and gently displacing each half laterally. In most preparations, the M-axons were visible crossing the midline and extending laterally toward their cell of origin. The M-cell somata could not be seen because they are about 200-250 $\mu \mathrm{m}$ below the surface of the medulla oblongata. The spinal cord was exposed a few centimeters anterior to the caudal peduncle, and bipolar stainlesssteel stimulating electrodes were placed on vertebrae over the cord to antidromically activate the M-cells. The white grunt M-cell was located about $300 \mu \mathrm{m}$ lateral to the midline and at a rostro-caudal level that was approximately centered on the cerebellum. A glass microelectrode $\left(3 \mathrm{~mol} \mathrm{~L}^{-1} \mathrm{KCl}, 3 \mathrm{~mol}\right.$ $\mathrm{L}^{-1} \Omega$ ) was lowered in steps into the brain to a maximum depth of $350 \mu \mathrm{m}$ while searching for the presence of a short-latency, antidromically evoked extracellular negative field potential. This all-or-none field potential is the hallmark signal of the M-cell action potential and is generated at the initial segment/axon hillock of the M-cell. Subsequent penetrations were spaced about 50-100 $\mu \mathrm{m}$ apart in a grid-like fashion to find the maximum field potential. A field potential of $10 \mathrm{mV}$ or greater was the criterion used to identify the presumed axon cap (Furshpan and Furukawa, 1962).

\section{Statistical analyses}

Two variables were calculated for each fish from images: (1) probability of eliciting a fast-start or responsiveness and (2) latency of the response, defined as the time interval from the auditory stimulus onset to the first movement of the head. An example of a fast-start is shown in Figure 2B, with the on- set of the stimulus (start) occurring in the first frame and the first movement of the fish head occurring in the second frame ( $8 \mathrm{~ms}$ after the start) and then sequential frames every $10 \mathrm{~ms}$.

The responsiveness of each fish for each treatment (i.e., baseline normoxia, hypoxia, etc.; Fig. 3) was calculated from the number of fast-starts that occurred in a set of six trials and was expressed as percent responsiveness. The latency of each fast-start was first calculated for each trial and then averaged for each set of six trials within a treatment. Only latencies equal to or less than $30 \mathrm{~ms}$ were used in statistical comparisons (Fig. 4; see Latency distributions).

Statistical comparisons were performed within groups between baseline normoxia and subsequent treatments. A oneway repeated-measure ANOVA with a Bonferroni post hoc test for comparison was used for the responsiveness of each group for data that were normally distributed. The latency of startle responses was not normally distributed; therefore, a Friedman one-way ANOVA was performed with a Dunn's post hoc test. The significance level was set at 0.05 . Prism 6
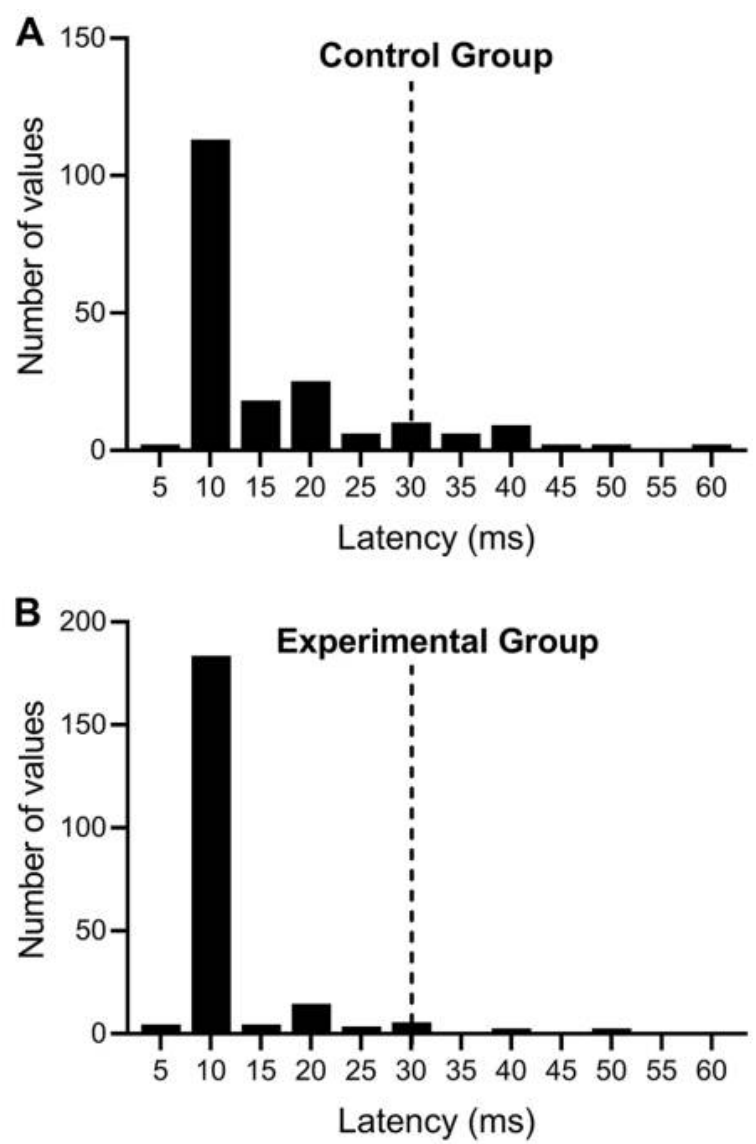

Figure 4. Distribution of startle response latencies for control and experimental treatments. (A) Latency distribution of control fast-starts of white grunts (Haemulon plumieri). Only fast-starts with latencies of $30 \mathrm{~ms}$ or less were used in the analysis (trials to the left of the dashed line). Of the trials with latencies of $\leq 30 \mathrm{~ms}$, control fish latencies averaged $12.76 \pm 0.42 \mathrm{~ms}$ (mean \pm SEM, $n=165$ ). (B) Latency distribution of experimental fast-starts of white grunts $(H$. plumieri). Latencies for experimental fish averaged $10.63 \pm$ $0.25 \mathrm{~ms}$ (mean $\pm \mathrm{SEM}, n=204)$. 
software (GraphPad Software, San Diego, CA) was used for all statistical analyses.

\section{Results}

We determined the initial body configuration (C-shape or S-shape) of a subset of experimental fish (9 of 18 fish) in response to an abrupt auditory stimulus. Of the 216 sound-test trials for these fish, there were 142 fast-starts; 131 of these were clearly a C-type response. We could not determine the configuration in 11 fast-starts because the fish hit the wall of the test chamber. Although we cannot exclude the presence of some S-starts in this study, the majority were C-type responses.

\section{Latency distributions}

Latency was measured as the first detectable movement of the head after the onset of an auditory stimulus. Latencies in control and experimental groups ranged from 7 to $60 \mathrm{~ms}$, with a total average latency of $13.23 \pm 0.41 \mathrm{~ms}$ (mean $\pm \mathrm{SEM}, n=$ 393). One outlier latency of $149 \mathrm{~ms}$ was excluded. Under the assumption that the shorter latency responses are M-cell initiated, we chose to analyze responses of $30 \mathrm{~ms}$ or less. This cutoff was chosen because putative M-cell-initiated fast-starts of goldfish, of comparable body lengths to white grunts, have latencies with an upper limit of $30 \mathrm{~ms}$ (DiDomenico et al., 1988; Zottoli et al., 1999). Control fish latencies (30 ms or less) averaged $12.76 \pm 0.42 \mathrm{~ms}$ (mean $\pm \mathrm{SEM}, n=165$; Fig. 4A). Latencies for experimental fish averaged $10.63 \pm$ $0.25 \mathrm{~ms}$ (mean \pm SEM, $n=204$; Fig. 4B). These white grunt latencies are similar to those reported in the literature for faststarts elicited by acoustic stimuli in goldfish $(11.5 \pm 0.3 \mathrm{~ms}$, mean \pm SE: Preuss and Faber, 2003; $12.4 \pm 0.5$ ms: Mirjany et al., 2011).

\section{Responsiveness and latency of fast-starts}

The probability of eliciting fast-start responses of the control group $(n=12)$ showed no significant difference between the three normoxic treatments (i.e., baseline normoxia [85\% average responsiveness], normoxia [75\%], and reversal normoxia [75\%]) (one-way ANOVA, $F_{2,22}=1.554, n=12$, $P=0.2336$; Fig. 5A). The one-way ANOVA also showed no significant differences within treatments (one-way ANOVA, $\left.F_{11,22}=1.177, n=12, P=0.3565\right)$. As a result, habituation of fast-start responses and handling of fish did not influence our results; therefore, we made within-group comparisons between baseline normoxia and other DO treatments.

The probability of eliciting fast-start responses of the experimental group $(n=18)$ showed significant difference between treatments after exposure to $2.5 \mathrm{mg} \mathrm{L}^{-1}$ of oxygen (40\% DO) $\left(F_{2,34}=22.6, n=18, P<0.0001\right.$; Fig. 5B $)$, with a significant decrease in fast-start occurrence between baseline normoxia (83\% average responsiveness), hypoxia (55\%), and reversal normoxia (54\%) (Bonferroni's post hoc comparison, $P \leq 0.0001$ ).
Unlike the control group, the responsiveness of individual fish showed high variability (one-way ANOVA, $F_{17,34}=6.99, n=$ $18, P<0.0001)$.

Latency of responses for both the control group $(n=12)$ and the experimental group $(n=16)$ did not show significant difference between treatments (control group: Friedman's $X^{2}=1.830, \mathrm{df}=3, n=12, P=0.4006$, Fig. 5C; experimental group: Friedman's $X^{2}=1.300, \mathrm{df}=3, n=16, P=0.5220$, Fig. 5D).

Twelve of the 18 experimental fish were tested $24 \mathrm{~h}$ after the return to normoxia (reversal normoxia 24 h; Fig. 6A). The probability of eliciting fast-start responses showed significant difference between treatments (one-way ANOVA, $F_{3,33}=$ $13.85, n=12, P<0.0001)$. A significant decrease in fast-start responsiveness was found when baseline normoxia (83\%) was compared with hypoxia (56\%), reversal normoxia (49\%), and reversal normoxia $24 \mathrm{~h}(51 \%)$ (Bonferroni's post hoc comparison, $P \leq 0.0001$ ). Thus, the reduced responsiveness continued for at least $24 \mathrm{~h}$ after fish were returned to normoxic conditions. The latency of the response was not different when baseline normoxia was compared to the other DO treatments (Friedman's $X^{2}=4.307, \mathrm{df}=4, n=11, P=0.2302$, Fig. 6B).

\section{Morphological and electrophysiological identification of the Mauthner cells}

M-cells are located about $225 \mu \mathrm{m}$ below the surface of the medulla oblongata. The left and right cells from one fish are shown in Figure 7A, B. The axons of these neurons are out of the plane of these $15-\mu \mathrm{m}$ sections; and, as a result, we have placed a line (Fig. 7A, B) to represent the trajectory of the axons. These large neurons have a composite axon cap with a central core and a peripheral portion surrounded by glia (only the glia nuclei are seen in these light micrographs; arrows, Fig. 7A, B). Processes of putative passive hyperpolarizing potential (PHP) neurons can also be seen outside the glial layer (see Bierman et al., 2009). The white grunt M-cell responds to threshold stimulation in an all-or-none manner (Fig. 7C). The short-latency negative field is followed by the so-called extrinsic hyperpolarizing potential (EHP). The maximum amplitude of both potentials occurs at the same depth as shown in the vertical profile of Figure 7D. The microelectrode was moved in steps from the surface of the medulla oblongata ventrally to a maximum depth of $325 \mu \mathrm{m}$. The depth of the largest extracellular negative spike and positive EHP was around $225 \mu \mathrm{m}$ ventral from the surface of the medulla oblongata. Increasing the stimulus frequency from 1/s (Fig. 7E, upper trace) to 4/s (Fig. 7, middle trace and lower trace) does not affect the all-or-none negative spike but does eventually eliminate the EHP. The stimulus frequency effect on the EHP is also shown by double antidromic activation of the M-cell. In the upper trace of Figure 7F, the first stimulus elicits a negative field and EHP, while the second stimulus elicits only the negative field. In the lower trace of Figure 7F, only the EHP is activated 

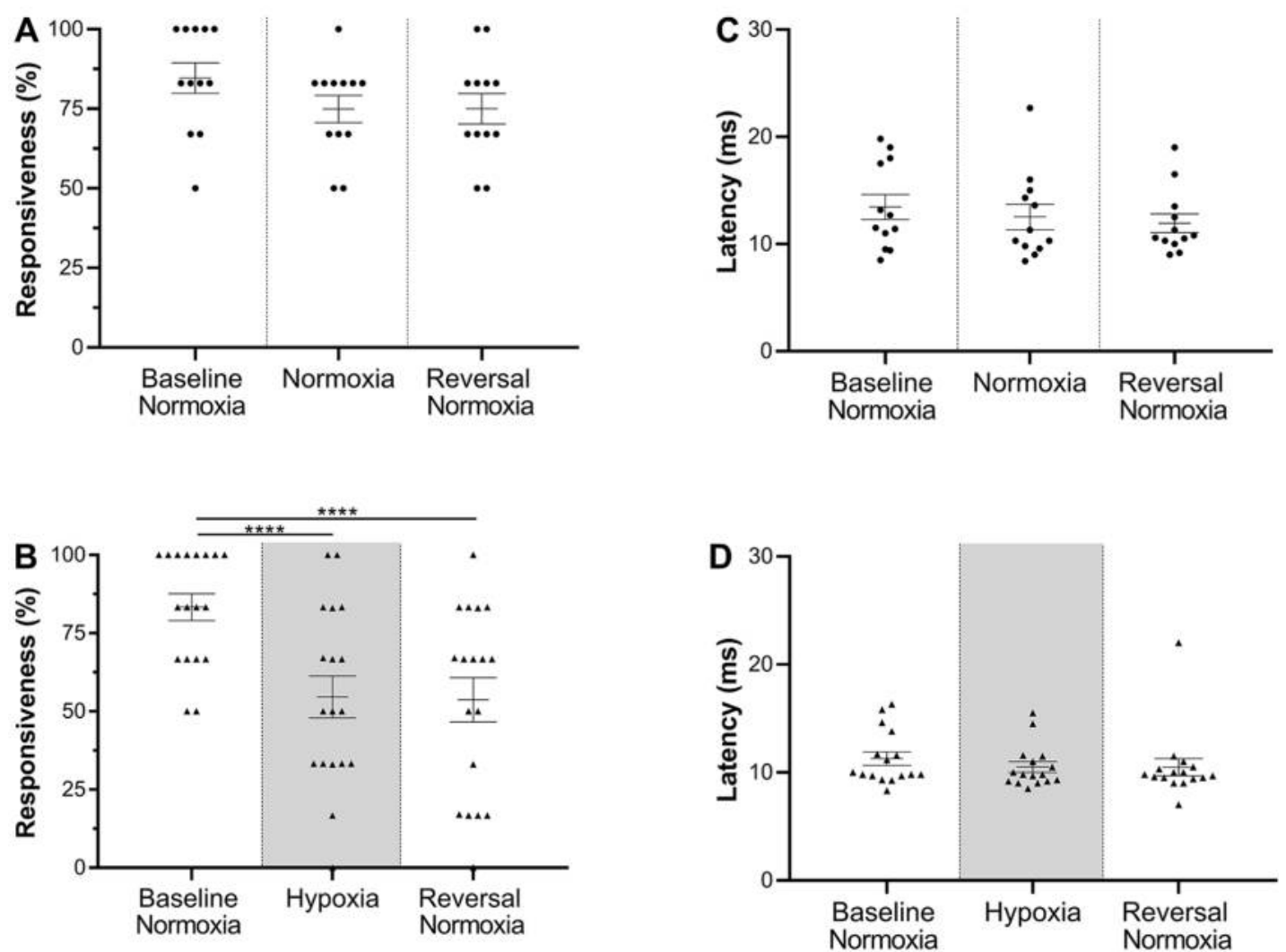

Figure 5. Responsiveness and latency of white grunt (Haemulon plumieri) fast-starts to a single hypoxic exposure. (A) Comparison of the responsiveness of the control group $(n=12)$. No significant differences were observed between treatments (one-way ANOVA, $F_{2,22}=1.554, n=12, P=0.2336$ ). Each point represents the responsiveness of each fish, the line represents the treatment average, and the error bars show the SEM. (B) Comparison of the responsiveness of the experimental group $(n=18)$ between baseline normoxia and the subsequent conditions of the single hypoxic protocol. There was a significant reduction in the probability of eliciting fast-starts between the baseline normoxic treatment and the hypoxic treatment (gray area) and between the baseline normoxic treatment and the reversal normoxia treatment (one-way ANOVA, $F_{2,34}=22.6, n=18, P<0.0001$ ). (C) Comparison of the latency of response in the control group $(n=12)$. No significant differences were observed between treatments (Friedman's $X^{2}=1.830, \mathrm{df}=3, n=12, P=0.4006$ ). Each point represents the average latency of the six trials per treatment for each fish. (D) Comparison of the latency of response in the experimental group $(n=16)$ between the baseline normoxia treatment and the subsequent treatments of the single hypoxic protocol (gray area). No significant differences were observed between treatments (Friedman's $X^{2}=1.300, \mathrm{df}=3, n=16, P=$ 0.5220). $* P<0.05 ; * * P<0.01 ; * * * P<0.001 ; * * * P<0.0001$.

to the first stimulus. The small negative field recorded in response to the first stimulus suggests a failure of invasion of the action potential to the recording site. The second stimulus does not elicit an EHP as a result of the short interval between stimuli. Neurons were encountered in the vicinity of maximal negative field recordings that had physiological properties of PHP neurons (Korn and Faber, 1975a).

\section{Discussion}

Exposure of the white grunt to hypoxic levels that occur in its natural habitat of Condado Lagoon resulted in a decrease in the probability of eliciting fast-starts. The reduced responsiveness continued for at least $24 \mathrm{~h}$ after return to normoxic conditions. This continued behavioral impairment has farreaching implications for survival even when fish are exposed to hypoxic conditions for relatively short periods of time. Indeed, the other lagoons in the SJBE often experience even lower oxygen levels than those observed in Condado (San Juan Bay Water Quality Monitoring Program; Table A2) and may be more representative of tropical urban estuary systems. Since fast-starts are thought to be important for escape from predation (Eaton and Hackett, 1984; Eaton et al., 2001), future studies are needed to determine the effect of hypoxia on predation rates of juvenile white grunts.

The responses of marine animals to hypoxic conditions can occur at the molecular, biochemical, physiological, behavioral, and ecosystem levels (Wu, 2002; Richards, 2011). Some 


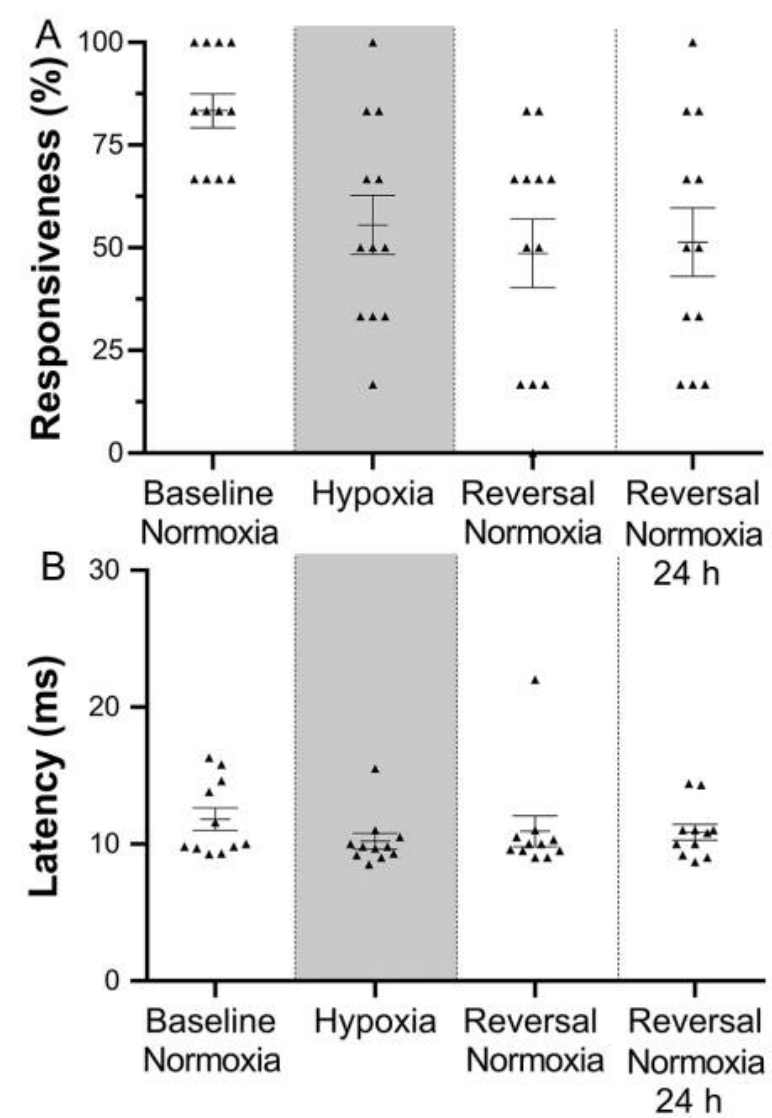

Figure 6. A reduction in responsiveness of white grunt (Haemulon plumieri) extends beyond hypoxic treatment (gray area) after return to normoxia. Twelve of the 18 experimental fish were tested $24 \mathrm{~h}$ after the return to normoxic conditions. (A) Comparison of baseline normoxia with hypoxia, reversal normoxia, and reversal normoxia $24 \mathrm{~h}$ treatments. The probability of eliciting a fast-start at $24 \mathrm{~h}$ was significantly less than baseline normoxia (one-way ANOVA, $F_{3,33}=13.85, n=12, P<0.0001$; Bonferroni's post hoc comparison, baseline $v s$. reversal $24 \mathrm{~h}, P=0.0001$ ). Each point represents the responsiveness of a fish, the line represents the treatment average, and the error bars show the SEM. (B) Latency values of experimental group with reversal normoxia $24 \mathrm{~h}$ treatment. The latency of the response was not different from baseline normoxia (Friedman's $X^{2}=4.307, \mathrm{df}=4, n=11$, $P=0.2302$ ). Each point represents the average latency of the six trials per treatment for each fish. ${ }^{*} P<0.05 ; * * P<0.01 ; * * * P<0.001 ; * * * * P<$ 0.0001 .

examples of behavioral effects of hypoxia include decreased locomotor activity (Lefrançois et al., 2005; Cannas et al., 2012; Aboagye and Allen, 2014), reduced feeding (Stierhoff et al., 2006; Chabot and Claireaux, 2008; Gamperl and Driedzic, 2009), changes in dominance hierarchy (Sneddon and Yerbury, 2004), and reduced schooling behavior (Domenici et al., 2002; Lefrançois et al., 2009). Some physiological effects of hypoxia include changes in cardiovascular function (Shingles et al., 2005), respiratory patterns (Saint-Paul, 1984; Wannamaker and Rice, 2000; Perry et al., 2009; Cannas et al., 2012), reproduction and development (Wu, 2009), and digestion (Wang et al., 2009). Other effects of hypoxia are related to oxygen uptake and include changes in gill structure (reviewed in Harper and Wolf, 2009), hemoglobin binding affinities (Wells, 2009), and tissue oxygen demands (Hopkins and Powell, 2001; Chabot and Claireaux, 2008). The short hypoxic exposure times used in this study would most likely affect respiration and cardiovascular function and possibly locomotor activity. Whether these possible changes could affect fast-starts of the white grunt is doubtful, although we cannot eliminate them as factors at this time.

\section{Behavioral adaptations of fishes to hypoxia}

The critical oxygen level $\left(P_{\text {crit }}\right)$ is a threshold below which the fish can no longer maintain a stable rate of oxygen uptake (Nilsson and Östlund-Nilsson, 2004; Mandic et al., 2009). The $P_{\text {crit }}$ of reef fishes in a lagoon outside of the Lizard Island Research Station in Queensland, Australia (31 species of fishes in 17 families), ranged from 0.78 to $2.04 \mathrm{mg} \mathrm{L}^{-1}(13 \%-34 \%$ of air saturation, $28-31{ }^{\circ} \mathrm{C}$ ). This range of oxygen concentrations is less than that used in this study $\left(2.5 \mathrm{mg} \mathrm{L}^{-1}\right)$, and we did not observe either agitation or loss of equilibrium of any fish. Therefore, we conclude that oxygen levels used to create hypoxia in this study were above $P_{\text {crit }}$ for the white grunt.

When fish are exposed to low oxygen conditions, they need to balance energy conservation and avoidance. Some larval, juvenile, and adult fish reduce movement activity when exposed to mild hypoxia (reviewed in Ekau et al., 2010). Atlantic cod display an initial increase followed by a decrease in swimming speed in response to short-term, acute hypoxia (Johansen et al., 2006). The initial increase in swimming speed has been interpreted as a response to avoid hypoxia (Herbert and Steffensen, 2005). White grunts were not able to avoid hypoxia in this study, whereas they would likely move under similar hypoxic conditions in Condado Lagoon. Even with avoidance in the wild, minutes of exposure to hypoxia are likely.

Behavioral adaptations such as aquatic emergence (airbreathing) or aquatic surface respiration (ASR) (reviewed in Lewis, 1970 and Richards, 2011; see also Kramer and Mehegan, 1981; Kramer, 1987; Shingles et al., 2005; Chapman and McKenzie, 2009) help maintain oxygen levels above $P_{\text {crit }}$ and increase fish tolerance to oxygen stress (Wu, 2002; Chapman and McKenzie, 2009; Mandic et al., 2009; Richards, 2009, 2011; Wells, 2009). Ninety-four percent of tropical freshwater fish studied utilized ASR under hypoxic conditions (Kramer and McClure, 1982), and $72 \%$ of species from marine habitats subject to hypoxia used this strategy (Kramer et al., 1983). Branchial respiration near the water surface increases the ability of fish to extract oxygen and creates a variable that can confound the relationship between hypoxia and behavioral changes such as we have seen with fast-starts. We did not observe ASR or aerial emergence by the white grunt during any phase of this 

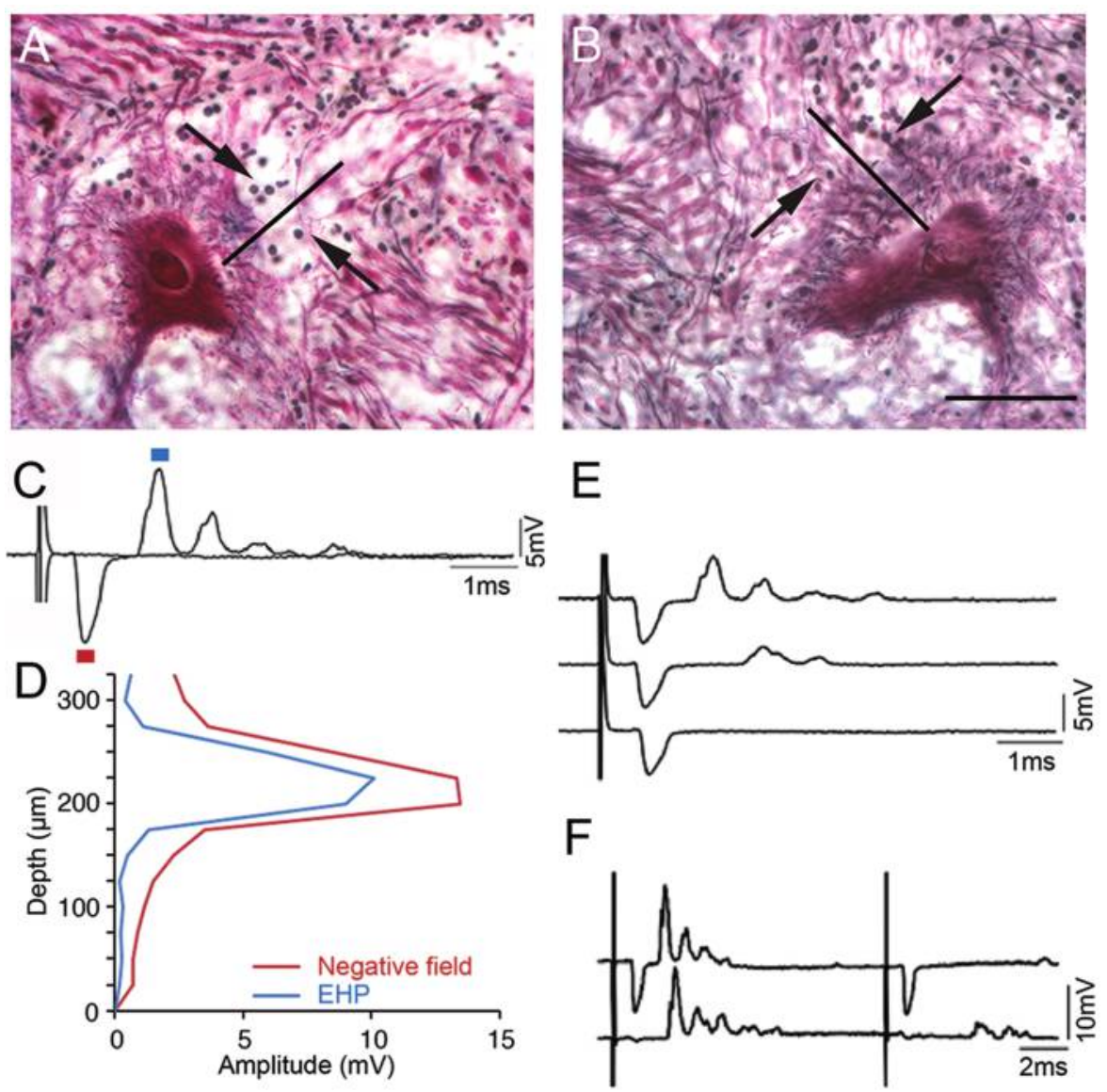

Figure 7. Morphological and physiological identification of Mauthner cells (M-cells) in a white grunt (Haemulon plumieri). (A, B) Pictures of transverse sections $(15 \mu \mathrm{m})$ taken at the level of the left and right M-cells in the medulla oblongata. Lines mark the approximate trajectory of the M-axon, which is out of the plane of the sections. Arrows indicate nuclei of glial cells that surround the axon cap. Dorsal is up, and the midline is between the two pictures (calibration $=50 \mu \mathrm{m}$ ). (C) The all-or-none nature of the M-cell recorded extracellularly at the level of the axon cap. Subthreshold stimulation of the spinal cord results in no response, while threshold stimulation evokes a negative field (red box) followed by an extrinsic hyperpolarizing potential (EHP; blue box). (D) The negative field and EHP amplitudes are maximal at the same depth. (E, F) The EHP is frequency labile. (E) Increasing the stimulation frequency from $1 / \mathrm{s}$ (upper trace) to $4 / \mathrm{s}$ (middle and lower traces) results in a reduction and, ultimately, the loss of the EHP. (F) Double antidromic stimulation of the M-cell. In the upper trace the first spinal cord stimulus evokes a negative field and EHP, while after the second there is no EHP. In the lower trace the stimulus elicits the EHP but not the negative field, presumably because the action potential fails to invade the axon hillock of the cell. The second stimulus fails to elicit the EHP due to the short interval between stimuli.

study. As a result, hypoxia levels in this study were not altered by extraction of oxygen from the water surface or air.

\section{Comparison of hypoxic effects between temperate and tropical fishes}

Hypoxia decreases fast-start responsiveness in temperate fishes (golden grey mullet, Liza aurata: Lefrançois et al., 2005; European sea bass, Dicentrarchus labrax: Lefrançois and Domenici, 2006). We have found comparable results utilizing the white grunt, a tropical fish. The latency of fast-starts is not affected by hypoxia in either tropical or temperate fishes. Temperate fishes exposed to hypoxia lost left-right discrimination, as displayed by the fish's random initial direction in response to stimuli. However, the startle trajectory is ultimately away from the stimulus (Lefrançois et al., 2005; Lefrançois and Domenici, 2006). We were not able to study left-right discrimination because our stimulus was non-directional.

A DO level of $2.8 \mathrm{mg} \mathrm{L}^{-1}$ (Diaz and Rosenberg, 1995) has been used to define hypoxia that can result in the impairment of fisheries (Diaz, 2001; Vaquer-Sunyer and Duarte, 2008); however, Vaquet-Sunyer and Duarte (2008) point out that this level underestimates sensitivity thresholds for most benthic organisms and that $4.6 \mathrm{mg} \mathrm{L}^{-1}$ would be more representative. Both the hypoxia DO levels of this study $\left(2.5 \mathrm{mg} \mathrm{L}^{-1}\right.$ DO) and those of temperate fishes $\left(1.5-1.9 \mathrm{mg} \mathrm{L}^{-1}\right)$ fall below the defined level of hypoxia, but future studies will be needed to test the threshold levels for DO effects on fast-starts 
and on how predators might be affected in conditions that increase prey risk.

What is the neuronal basis for the reduced responsiveness to hypoxia?

Two types of fish startle responses have been described, and they differ in their initial body conformation: (1) C-start responses, where initial movement is in the form of a C-shaped body bend, and (2) S-start responses, where the initial movement is in the form of an S-shaped body bend (Hale, 2002; Schriefer and Hale, 2004; Liu et al., 2012; Liu and Hale, 2017). Head stimulation generally elicits C-starts, while tail stimulation can elicit both C- and S-starts (Liu et al., 2012). An analysis of a subset of startle responses in this study indicated that the majority are C-type responses. C-starts in adult goldfish elicited by auditory stimulation typically result from activation of one M-cell (M-cell; Zottoli, 1977; Eaton et al., 1981). However, parallel pathways are revealed after M-cell ablation such that fish display non-M-cell C-starts that are mechanically similar to M-cell responses but that have significantly longer latencies, on average (Eaton et al., 1982; DiDominico et al., 1988; Liu and Fetcho, 1999; Zottoli et al., 1999; Nakayama and Oda, 2004; Kohashi and Oda, 2008; Neki et al., 2014).

We cannot exclude that some of the responses in this study might be non-M-cell initiated due to an overlap in the range of latencies with M-cell responses (DiDomenico et al., 1988; Zottoli et al., 1999). By restricting our analysis to include faststarts within the range of latencies of putative M-cell-initiated responses in the goldfish (DiDomenico et al., 1988; Zottoli et al., 1999; $\leq 30 \mathrm{~ms}$ ), we speculate that most of the shortlatency responses are M-cell initiated.

The accessibility of the M-cell network was an important motivator for us to characterize the white grunt M-cell (Fetcho and Faber, 1988; Faber et al., 1989; Eaton et al., 2001; Satou et al., 2009; Liu and Hale, 2017; Shimazaki et al., 2018) because not all fishes have M-cells (Zottoli, 1978; Stefanelli, 1980). Thus, an important first step to study how hypoxia affects the startle response circuitry was to determine whether M-cells exist in the white grunt. We were able to characterize the M-cell both morphologically and electrophysiologically. The white grunt M-cell was located in segment 4 of the hindbrain (Lee et al., 1993), and it had a distinctive structure: the axon cap, surrounding the axon hillock and initial segment portion of the cell. The presence of glial cell nuclei and a complex array of fibers indicates that the axon cap has a composite structure (Bierman et al., 2009). We have described in the white grunt the signature negative field potential and EHP characteristic of M-cells with composite axon caps (goldfish: Furshpan and Furukawa, 1962; winter flounder: Zottoli, 1981; sea robin: Zottoli et al., 2011). The characterization of these potentials in association with the white grunt axon cap allows (1) the unequivocal physiological identification of the M-cell from fish to fish, (2) the ability to identify other cellular locations utilizing the axon cap as a landmark, and (3) the ability to record from synaptic inputs to the cell (see below). Such "signature potentials" will help in the localization of the site or sites affected by hypoxia.

Lowering oxygen levels of vestibular (bullfrog: Sitdo and Honrubia, 1986) and auditory (goldfish: Suzue et al., 1987) portions of the ear has been shown to decrease activity in afferents that project to the brain. A major fraction of the auditory input to the goldfish M-cell originates from the saccular portion of the ear where hair cells synapse on afferents that project to and synapse on the distal lateral dendrite (Furshpan and Furukawa, 1962; Furshpan, 1964; Furukawa, 1978; Lin et al., 1983; Zottoli et al., 1995; Szabo et al., 2006). Hypoxia reduces the excitatory postsynaptic potential at the synapse between saccular hair cells and large afferent fibers (S1 fibers of Furukawa and Ishii, 1967). Presynaptic mechanisms within hair cells appear to underlie this reduction (Suzue et al., 1987). Less excitation leads to a decrease in spontaneous activity and sensitivity of saccular afferents (S2 afferents, Fay and Ream, 1992; reviewed in Fay, 1995). Since afferents are less responsive to sound stimulation in hypoxic conditions (see also Fay and Ream, 1992; reviewed in Fay, 1995), the probability that the M-cell will reach threshold is lessened and could explain fewer fast-starts of the white grunt to hypoxia under the assumption that the white grunt M-cell receives saccular inputs similar to those of the goldfish (Lin et al., 1983). Although lateral-line inputs to the M-cell (Faber and Korn, 1975; Korn and Faber, 1975b; Mirjany and Faber, 2011; Mirjany et al., 2011) are sensitive to low-frequency components of an acoustic stimulus, inactivation of lateral line hair cells with $\mathrm{CoCl}_{2}$ or gentamicin does not change the probability of eliciting faststart responses utilizing a stimulus similar to that used in this study (Mirjany et al., 2011). Thus, we speculate that the major effect of hypoxia is on the synapse between saccular hair cells and afferents that project to the M-cell and that this effect is responsible for changes in responsiveness of the white grunt to abrupt auditory stimuli. This hypothesis can be tested with simultaneous recordings from the saccular afferents and the M-cell distal lateral dendrite.

\section{Hypoxia and diversity and abundance of fish species}

Anthropogenic activities and increased water temperatures associated with climate change have contributed to an increase in hypoxic conditions in nearshore ecosystems worldwide (Diaz et al., 1992; Jackson, 2008; Rabalais et al., 2009; Zhang et al., 2010; Altieri et al., 2017; Van Meter et al., 2018). An increase in the occurrence of hypoxia has been reported throughout the Caribbean, where more than 25 eutrophic and hypoxic coastal zones have been identified (Ellison and Farnsworth, 1996; Diaz, et al., 2011). Condado Lagoon water quality data indicate that values between $60 \%$ and $80 \%$ DO have become more common, with $40 \%$ DO $\left(2.5 \mathrm{mg} \mathrm{L}^{-1}\right)$ 
the lowest recorded hypoxic event to date. Although DO levels below $40 \%$ have not been reported in the lagoon, a pattern of increasing frequency of low-DO events has been documented in the past few years, mainly during Puerto Rico's wet season (Lugo et al., 2011). An increase in hypoxic events has important management and conservation implications not only for Condado Lagoon but also for the other four lagoons in the San Juan Bay Estuary system with even lower water quality (San Juan Bay Water Quality Monitoring Program; Table A2).

Hypoxia can have a negative impact on species richness and abundance (Pihl et al., 1991; Killgore and Hoover, 2001; Altieri et al., 2017). Species that inhabit nursery ecosystems such as Condado Lagoon at early life stages (e.g., eggs and larvae) will be susceptible to oxygen stress because they have limited mobility and thus cannot easily avoid hypoxic conditions (Breitburg et al., 1994; Levin et al., 2009). Studies on red drum (Sciaenops ocellatus) larvae highlight the importance of "exceptional behavioral skills" such as startle responses in the survival of an individual (Fuiman and Cowan, 2003). If the exposure to hypoxic conditions does not result in death, a reduction in startle responsiveness may expose larvae to increased predation (Fuiman et al., 2006). Although a hypoxic environment can provide an advantage to a predator of DO-stressed prey (Diaz and Breitburg, 2009), fish more often move to avoid hypoxia, despite the increased risk of predation due to the loss of protective cover (reviewed in Wolf and Kramer, 1987; Pihl et al., 1991; Chapman and McKenzie, 2009). Many adult and juvenile fishes, however, are able to detect and avoid hypoxic conditions (Jones, 1952; Wannamaker and Rice, 2000; Karim et al., 2003) with resultant changes in distribution (Pihl et al., 1991).

Laboratory results such as reported here are useful to qualitatively identify possible mechanism of effects in field conditions. In this study fish spent about $30 \mathrm{~min}$ in oxygen levels of $2.5 \mathrm{mg} \mathrm{L}^{-1}$ (40\% DO) and $30 \mathrm{~min}$ in partial hypoxic conditions (i.e., shifts between treatments; Fig. 3). Similar hypoxic effects have been reported after exposure of temperate fish to $\mathrm{O}_{2}$ levels between 1.5 and $1.9 \mathrm{mg} \mathrm{L}^{-1}$ for $15-20 \mathrm{~min}$ and partial hypoxic conditions for $90 \mathrm{~min}$ (Lefrançois et al., 2005; Lefrançois and Domenici, 2006). The duration of a fish's exposure in the field depends on many factors, including the ability of the fish to leave hypoxic zones. Exposure of fish to hypoxia in the laboratory coupled with predator-prey studies in the field will provide important information on how hypoxia might affect predation rates of juveniles.

In this study, we examined a single sub-lethal stressor, but multiple stressors may be acting at the same time (e.g., decreased $\mathrm{pH}$, increased temperature, and exposure to toxic pollutants) in the field. We may be underestimating the possible impacts of environmental changes on the responsiveness and survival of fishes and, thus, the more far-reaching effects on the distribution, abundance, and diversity of fish and other species in complex nearshore marine habitats. The response of white grunts from well-oxygenated, uncontaminated water to hypoxia will aid in the understanding of how concurrent stresses impact sensitivity.

\section{Acknowledgments}

Steve Treistman and the Institute of Neurobiology in Old San Juan, Puerto Rico, kindly hosted SJZ, and Dr. Cristina Velazquez and Dr. Hector Marrero provided essential assistance in the laboratory. We thank Kamran Khodakhah for reading an earlier version of this manuscript and Frank P. Elsen, Electrophysiology Application Scientist of Harvard Bioscience, for his kind help. We also thank undergraduate students at the University of Puerto Rico for their help in the collection and care of fish. This research was supported by Williams College, the Puerto Rico Center for Environmental Neuroscience, and a National Science Foundation Centers of Research Excellence in Science and Technology grant (HRD-1137725).

\section{Ethical Care}

Thirty white grunts (Haemulon plumieri), $8-11 \mathrm{~cm}$ in total length, were collected (collection permits R-VS-PVS15-SJ00409-290814 and R-VS-PV15-SJ-00482-02092015) in Condado Lagoon with a cast net, and they were transported and held in tanks at the same salinity and temperature as in the lagoon. Experimental fish were exposed to hypoxia, which had no visible effects on their equilibrium; and no fish died during the hypoxic sequence. After the behavioral experiments, fish were returned to the lagoon. Two fish were sacrificed for histological observation, and five fish were used for electrophysiological studies. The handling, anesthesia, and euthanizing protocols of these fish were reviewed and approved in accordance with National Institutes of Health ethical guidelines (Institutional Animal Care and Use Committee protocols 00819-08-16-2013 and 01006-01-09-2015).

\section{Literature Cited}

Aboagye, D. L., and P. J. Allen. 2014. Metabolic and locomotor responses of juvenile paddlefish Polyodon spathula to hypoxia and temperature. Comp. Biochem. Physiol. A Mol. Integr. Physiol. 169: 51-59.

Ahn, J. H., S. B. Grant, C. Q. Surbeck, P. M. DiGiacomo, N. P. Nezlin, and S. Jiang. 2005. Coastal water quality impact of stormwater runoff from an urban watershed in southern California. Environ. Sci. Technol. 39: 5940-5953.

Alpuche-Gual, L., and G. Gold-Bouchot. 2008. Determination of esterase activity and characterization of cholinesterases in the reef fish Haemulon plumieri. Ecotoxicol. Environ. Saf. 71: 787-797.

Altieri, A. H., S. B. Harrison, J. Seemann, R. Collin, R. J. Diaz, and N. Knowlton. 2017. Tropical dead zones and mass mortalities on coral reefs. Proc. Natl. Acad. Sci. U.S.A. 114: 3660-3665.

Beck, M. W., K. L. Heck, K. W. Able, D. L. Childers, D. B. Eggleston, B. M. Gillanders, B. Halpern, C. G. Hays, K. Hoshino, T. J. Minello et al. 2001. The identification, conservation, and management of estuarine and marine nurseries for fish and invertebrates. BioScience 51: 633.

Bierman, H. S., S. J. Zottoli, and M. E. Hale. 2009. Evolution of the Mauthner axon cap. Brain Behav. Evol. 73: 174-187. 
Breitburg, D. L., N. Steinberg, S. DuBeau, C. Cooksey, and E. D. Houde. 1994. Effects of low dissolved oxygen on predation on estuarine fish larvae. Mar. Ecol. Prog. Ser. 104: 235-246.

Canfield, J. G., and G. J. Rose. 1993. Activation of Mauthner neurons during prey capture. J. Comp. Physiol. A Neuroethol. Sens. Neural Behav. Physiol. 172: 611-618.

Cannas, M., P. Domenici, and C. Lefrançois. 2012. The effect of hypoxia on ventilation frequency in startled common sole Solea solea. $\underline{J}$. Fish Biol. 80: 2636-2642.

Catania, K. C. 2009. Tentacled snakes turn C-starts to their advantage and predict future prey behavior. Proc. Natl. Acad. Sci. U.S.A. 106: 11183-11187.

Chabot, D., and G. Claireaux. 2008. Environmental hypoxia as a metabolic constraint on fish: the case of Atlantic cod, Gadus morhua. Mar. Pollut. Bull. 57: 287-294.

Chapman, L. J., and D. J. McKenzie. 2009. Behavioral responses and ecological consequences. Fish Physiol. 27: 25-77.

Courtenay, W. R. 1961. Western Atlantic fishes of the genus Haemulon (Pomadasyidae): systematic status and juvenile pigmentation. Bull. Mar. Sci. 11: 1-136.

Darcy, G. H. 1983. Synopsis of biological data on the grunts Haemulon aurolineatum and H. plumieri (Pisces: Haemulidae). National Oceanic and Atmospheric Administration Technical Report, National Marine Fisheries Service Circular No. 448, Food and Agriculture Organization of the United Nations (FAO) Fisheries Synopsis No. 133. FAO, Rome.

De Silva, J. A., and M. D. Murphy. 2001. A Summary of the Status of White Grunt Haemulon plumieri from the East Coast of Florida. Florida Fish Wildlife Commission, Florida Marine Research Institute, St. Petersburg.

Dennis, G. D. 1992. Island mangrove habitats as spawning and nursery areas for commercially important fishes in the Caribbean. Proc. Gulf Caribb. Fish. Inst. 41: 205-225.

Diaz, R., M. Selman, and C. Chique. 2011. Global eutrophic and hypoxic coastal systems. Eutrophication and hypoxia: nutrient pollution in coastal waters, Washington, DC, World Resources Institute. [Online]. Available: https://wedocs.unep.org/bitstream/handle/20.500.11822 /19229/eutrophication_and_hypoxia_in_coastal_areas.pdf?sequence $=1$ [2019, July 2].

Diaz, R. J. 2001. Overview of hypoxia around the world. Environ. Qual. 30: $275-281$.

Diaz, R. J., and D. L. Breitburg. 2009. The hypoxic environment. Fish Physiol. 27: 1-23.

Diaz, R. J., and R. Rosenberg. 1995. Marine benthic hypoxia: a review of its ecological effects and the behavioural responses of benthic macrofauna. Oceanogr. Mar. Biol. Annu. Rev. 33: 245-303.

Diaz, R. J., and R. Rosenberg. 2008. Spreading dead zones and consequences for marine ecosystems. Science 321: 926-929.

Diaz, R. J., R. J. Neubauer, L. C. Schaffner, L. Pihl, and S. P. Baden. 1992. Continuous monitoring of dissolved oxygen in an estuary experiencing periodic hypoxia and the effect of hypoxia on macrobenthos and fish. Pp. 1055-1068 in Marine Coastal Eutrophication. The Response of Marine Transitional Systems to Human Impact: Problems and Perspectives for Restoration, Proceedings of an International Conference, Bologna, Italy, 21-24 March 1990, R. A. Vollenweider, R. Marchetti, and R. Viviani, eds. Elsevier, Amsterdam.

DiDomenico, R., J. Nissanov, and R. C. Eaton. 1988. Lateralization and adaptation of a continuously variable behavior following lesions of a reticulospinal command neuron. Brain Res. 473: 15-28.

Domenici, P., R. S. Ferrari, J. F. Steffensen, and R. S. Batty. 2002. The effect of progressive hypoxia on school structure and dynamics in Atlantic herring Clupea harengus. Proc. R. Soc. B Biol. Sci. 269: 2103-2111.

Eaton, R. C., and J. T. Hackett. 1984. The role of the Mauthner cell in fast-starts involving escape in teleost fishes. Pp. 213-266 in Neural Mechanisms of Startle Behavior, R. C. Eaton, ed. Springer, Boston.
Eaton, R. C., W. A. Lavender, and C. M. Wieland. 1981. Identification of Mauthner-initiated response patterns in goldfish: evidence from simultaneous cinematography and electrophysiology. J. Comp. Physiol. A Neuroethol. Sens. Neural Behav. Physiol. 144: 521-531.

Eaton, R. C., W. A. Lavender, and C. M. Wieland. 1982. Alternative neural pathways initiate fast-start responses following lesions of the Mauthner neuron in goldfish. J. Comp. Physiol. A Neuroethol. Sens. Neural Behav. Physiol. 145: 485-496.

Eaton, R. C., R. K. Lee, and M. B. Foreman. 2001. The Mauthner cell and other identified neurons of the brainstem escape network of fish. Prog. Neurobiol. 63: 467-485.

Ekau, W., H. Auel, H.-O. Pörtner, and D. Gilbert. 2010. Impacts of hypoxia on the structure and processes in pelagic communities (zooplankton, macro-invertebrates and fish). Biogeosciences 7: 1669-1699.

Ellison, A. M., and E. J. Farnsworth. 1996. Anthropogenic disturbance of Caribbean mangrove ecosystem: past impacts, present trends, and future predictions. Biotropica 28: 549-565.

Faber, D. S., and H. Korn. 1975. Inputs from the posterior lateral line nerves upon the goldfish Mauthner cells. II. Evidence that the inhibitory components are mediated by interneurons of the recurrent collateral network. Brain Res. 96: 349-356.

Faber, D. S., J. R. Fetcho, and H. Korn. 1989. Neuronal networks underlying the escape response in goldfish: general implications for motor control. Ann. N.Y. Acad. Sci. 563: 11-33.

Fay, R. R. 1995. Physiology of primary saccular afferents of goldfish: implications for Mauthner cell response. Brain Behav. Evol. 46: 141-150.

Fay, R. R., and T. J. Ream. 1992. The effects of temperature change and transient hypoxia on auditory nerve fiber response in the goldfish (Carassius auratus). Hear. Res. 58: 9-18.

Fetcho, J. R., and D. S. Faber. 1988. Identification of motoneurons and interneurons in the spinal network for escapes initiated by the Mauthner cell in goldfish. J. Neurosci. 8: 4192-4213.

Fuiman, L. A., and J. H. Cowan, Jr. 2003. Behavior and recruitment success in fish larvae: repeatability and covariation of survival skills. Ecology 84: 53-67.

Fuiman, L. A., K. A. Rose, J. H. Cowan, Jr., and E. P. Smith. 2006. Survival skills required for predator evasion by fish larvae and their relation to laboratory measures of performance. Anim. Behav. 71: 1389-1399.

Furshpan, E. 1964. Electrical transmission at an excitatory synapse in a vertebrate brain. Science 144: 878-880.

Furshpan, E., and T. Furukawa. 1962. Intracellular and extracellular responses of the several regions of the Mauthner cell of the goldfish. J. Neurophvsiol. 25: 732-771.

Furukawa, T. 1978. Sites of termination on the saccular macula of auditory nerve fibers in the goldfish as determined by intracellular injection of procion yellow. J. Comp. Neurol. 180: 807-814.

Furukawa, T., and Y. Ishii. 1967. Neurophysiological studies on hearing in goldfish. J. Neurophvsiol. 30: 1377-1403.

Gamperl, A. K., and W. R. Driedzic. 2009. Cardiovascular function and cardiac metabolism. Fish Physiol. 27: 301-360.

Hale, M. E. 2002. S- and C-start escape responses of the muskellunge (Esox masquinongy) require alternative neuromotor mechanisms. J. Exp. Biol. 205: 2005-2016.

Harper, C., and J. C. Wolf. 2009. Morphologic effects of the stress response in fish. ILAR J. 50: 387-396.

Herbert, N. A., and J. F. Steffensen. 2005. The response of Atlantic cod, Gadus morhua, to progressive hypoxia: fish swimming speed and physiological stress. Mar. Biol. 147: 1403-1412.

Hopkins, S. R., and F. L. Powell. 2001. Common themes of adaptation to hypoxia: insights from comparative physiology. Adv. Exp. Med. Biol. 502: $153-167$.

Jackson, J. B. C. 2008. Ecological extinction and evolution in the brave new ocean. Proc. Natl. Acad. Sci. U.S.A. 105(suppl. 1): 11458-11465. 
Johansen, J. L., N. A. Herbert, and J. F. Steffensen. 2006. The behavioural and physiological response of Atlantic cod Gadus morhua L. to short-term acute hypoxia. J. Fish Biol. 68: 1918-1924.

Jones, J. R. E. 1952. The reactions of fish to water of low oxygen concentration. J. Exp. Biol. 29: 403-415.

Karim, M. R., M. Sekine, and M. Ukita. 2003. A model of fish preference and mortality under hypoxic water in the coastal environment. Mar. Pollut. Bull. 47: 25-29.

Killgore, K. J., and J. J. Hoover. 2001. Effects of hypoxia on fish assemblages in a vegetated waterbody. J. Aquat. Plant Manage. 39: 40-44.

Keeling, R. F. 2010. Ocean deoxygenation in a warming world. Annu. Rev. Mar. Sci. 2: 199-229.

Kennedy, R. H., J. J. Hains, W. A. Boyd, J. Lemons, and F. Herrmann. 1996. San Juan Bay and Estuary Study: Water Quality Data Collection No. EL-96-9. U.S. Army Engineer Waterways Experiment Station, Vicksburg, MS.

Kennish, M. J. 2002. Environmental threats and environmental future of estuaries. Environ. Conserv. 29: 78-107.

Kohashi, T., and Y. Oda. 2008. Initiation of Mauthner- or non-Mauthnermediated fast escape evoked by different modes of sensory input. J. Neurosci. 281: 10641-10653.

Korn, H., and D. S. Faber. 1975a. An electrically mediated inhibition in goldfish medulla. J. Neurophvsiol. 38: 452-471.

Korn, H., and D. S. Faber. 1975b. Inputs from the posterior lateral line nerves upon the goldfish Mauthner cell. I. Properties and synaptic localization of the excitatory component. Brain Res. 96: 342-348.

Kramer, D. L. 1987. Dissolved oxygen and fish behavior. Environ. Biol. Fish. 18: 81-92.

Kramer, D. L., and M. McClure. 1982. Aquatic surface respiration, a widespread adaptation to hypoxia in tropical freshwater fishes. Environ. Biol. Fish. 7: 47-55.

Kramer, D. L., and J. P. Mehegan. 1981. Aquatic surface respiration, an adaptive response to hypoxia in the guppy, Poecilia reticulata (Pisces, Poeciliidae). Environ. Biol. Fish. 6: 299-313.

Kramer, D. L., D. Manley, and R. Bourgeois. 1983. The effect of respiratory mode and oxygen concentration on the risk of aerial predation in fishes. Can. J. Zool. 61: 653-665.

Laegdsgaard, P., and C. R. Johnson. 1995. Mangrove habitats as nurseries: unique assemblages of juvenile fish in subtropical mangroves in eastern Australia. Mar. Ecol. Prog. Ser. 126: 67-81.

Lee, R. K., R. C. Eaton, and S. J. Zottoli. 1993. Segmental arrangement of reticulospinal neurons in the goldfish hindbrain. $\underline{\text { J. Comp. Neurol. 329: }}$ $539-560$.

Lefrançois, C., and P. Domenici. 2006. Locomotor kinematics and behaviour in the escape response of European sea bass, Dicentrarchus labrax L., exposed to hypoxia. Mar. Biol. 149: 969-977.

Lefrançois, C., A. Shingles, and P. Domenici. 2005. The effect of hypoxia on locomotor performance and behaviour during escape in Liza aurata. J. Fish Biol. 67: 1711-1729.

Lefrançois, C., R. S. Ferrari, J. Moreira Da Silva, and P. Domenici. 2009. The effect of progressive hypoxia on spontaneous activity in single and shoaling golden grey mullet Liza aurata. J. Fish Biol. 75: 16151625.

Levin, L., W. Ekau, A. J. Gooday, F. Jorissen, J. J. Middelburg, S. W. Naqvi, and J. Zhang. 2009. Effects of natural and human-induced hypoxia on coastal benthos. Biogeosciences 6: 2063-2098.

Lewis, W. M. 1970. Morphological adaptations of cyprinodontoids for inhabiting oxygen deficient waters. Copeia 1970: 319-325.

Lin, J. W., D. S. Faber, and M. R. Wood. 1983. Organized projection of the goldfish saccular nerve onto the Mauthner cell lateral dendrite. Brain Res. 274: 319-324.

Liu, K. S., and J. R. Fetcho. 1999. Laser ablations reveal functional relationships of segmental hindbrain neurons in zebrafish. Neuron 23: $325-335$.
Liu, Y.-C., and M. E. Hale. 2017. Local spinal cord circuits and bilateral Mauthner cell activity function together to drive alternative startle behaviors. Curr. Biol. 27: 697-704.

Liu, Y.-C., I. Bailey, and M. E. Hale. 2012. Alternate startle motor patterns and behaviors in the larval zebrafish (Danio rerio). J. Comp. Phvsiol. A Neuroethol. Sens. Neural Behav. Phvsiol. 198: 11-24.

Lugo, A. E., O. M. R. González, and C. R. Pedraza. 2011. The Río Piedras Watershed and Its Surrounding Environment No. FS-980. U.S. Department of Agriculture, Forest Service, International Institute of Tropical Forestry, Washington, DC.

Mandic, M., A. E. Todgham, and J. G. Richards. 2009. Mechanisms and evolution of hypoxia tolerance in fish. Proc. R. Soc. B Biol. Sci. 276: $735-744$.

Martinuzzi, S., W. A. Gould, A. E. Lugo, and E. Medina. 2009. Conversion and recovery of Puerto Rican mangroves: 200 years of change. For. Ecol. Manage. 257: 75-84.

Mirjany, M., and D. S. Faber. 2011. Characteristics of the anterior lateral line nerve input to the Mauthner cell. J. Exp. Biol. 214: 3368-3377.

Mirjany, M., T. Preuss, and D. S. Faber. 2011. Role of the lateral line mechanosensory system in directionality of goldfish auditory evoked escape response. J. Exp. Biol. 214: 3358-3367.

Nagelkerken, I., G. van der Velde, M. W. Gorissen, G. J. Meijer, T. van't Hof, and C. den Hartog. 2000. Importance of mangroves, seagrass beds and the shallow coral reef as a nursery for important coral reef fishes, using a visual census technique. Estuar. Coast. Shelf Sci. 51: 31-44.

Nakayama, H., and Y. Oda. 2004. Common sensory inputs and differential excitability of segmentally homologous reticulospinal neuron in the hindbrain. J. Neurosci. 24: 3199-3209.

Neki, D., H. Nakayama, T. Fujii, H. Matsui-Furusho, and Y. Oda. 2014. Functional motifs composed of morphologically homologous neurons repeated in the hindbrain segments. J. Neurosci. 34: 3291-3302.

Nilsson, G. E., and S. Östlund-Nilsson. 2004. Hypoxia in paradise: widespread hypoxia tolerance in coral reef fishes. Proc. R. Soc. B Biol. Sci. 271(suppl. 3): S30-S33.

Otero, E. 2011. Estuarine Environmental Indicators for the San Juan Bay Estuary: Assessment of Sediment and Fish Tissue Contaminants. San Juan Bay Estuary Program, Region 2, US Environmental Protection Agency, Washington, DC.

Paerl, H. W., J. L. Pinckney, J. M. Fear, and B. L. Peierls. 1998. Ecosystem responses to internal and watershed organic matter loading: consequences for hypoxia in the eutrophying Neuse River Estuary, North Carolina, USA. Mar. Ecol. Prog. Ser. 166: 17-25.

Palazón-Fernández, J. L. 2007. Reproduction of the white grunt, Haemulon plumieri (Lacépede, 1802) (Pisces: Haemulidae) from Margarita Island, Venezuela. Sci. Mar. 71: 429-440.

Perry, S. F., M. G. Jonz, and K. M. Gilmour. 2009. Oxygen sensing and the hypoxic ventilatory response. J. Fish Biol. 27: 193-253.

Pihl, L., S. P. Baden, and R. J. Diaz. 1991. Effects of periodic hypoxia on distribution of demersal fish and crustaceans. Mar. Biol. 108: 349-360.

Preuss, T., and D. S. Faber. 2003. Central cellular mechanisms underlying temperature-dependent changes in the goldfish startle-escape behavior. J. Neurosci. 23: 5617-5626.

Rabalais, N. N., R. E. Turner, R. J. Díaz, and D. Justić. 2009. Global change and eutrophication of coastal waters. ICES J. Mar. Sci. 66: 15281537.

Rees, B. B., T. E. Targett, B. J. Ciotti, C. A. Tolman, S. S. Akkina, and A. M. Gallaty. 2012. Temporal dynamics in growth and white skeletal muscle composition of the mummichog Fundulus heteroclitus during chronic hypoxia and hyperoxia. J. Fish Biol. 81: 148-164.

Richards, J. G. 2009. Metabolic and molecular responses of fish to hypoxia. Fish Physiol. 27: 443-485.

Richards, J. G. 2011. Physiological, behavioral and biochemical adaptations of intertidal fishes to hypoxia. J. Exp. Biol. 214: 191-199. 
Rosenberg, R. 1995. Benthic marine fauna structured by hydrodynamic processes and food availability. Neth. J. Sea Res. 34: 303-317.

Saint-Paul, U. 1984. Physiological adaptation to hypoxia of a neotropical characoid fish Colossoma macropomum, Serrasalmidae. Environ. Biol. Fish. 11: 53-62.

Satou, C., Y. Kimura, T. Kohashi, K. Horikawa, H. Takeda, Y. Oda, and S. Higashijima. 2009. Functional role of a specialized class of spinal commissural inhibitory neurons during fast escapes in zebrafish. J. Neurosci. 29: 6780-6793.

Schriefer, J. E., and M. E. Hale. 2004. Strikes and startles of northern pike (Esox lucius): a comparison of muscle activity and kinematics between S-start behaviors. J. Exp. Biol. 207: 535-544.

Shimazaki, T., M. Tanimoto, Y. Oda, and S.-I. Higashijima. 2018. Behavioral role of reciprocal inhibition between a pair of Mauthner cells during fast escapes in zebrafish. J. Neurosci. 39: 1182-1194.

Shimps, E. L., J. A. Rice, and J. A. Osborne. 2005. Hypoxia tolerance in two juvenile estuary-dependent fishes. J. Exp. Mar. Biol. Ecol. 325: 146162.

Shingles, A., D. J. McKenzie, G. Claireaux, and P. Domenici. 2005. Reflex cardioventilatory responses to hypoxia in the flathead grey mullet (Mugil cephalus) and their behavioural modulation by perceived threat of predation and water turbidity. Phvsiol. Biochem. Zool. 78: 744-755.

Sitdo, S., and V. Honrubia. 1986. Differential effects of ischemia on spontaneous and sinusoidal-evoked activity in semicircular canal afferents in the bullfrog. Acta Otolarvngol. 102: 179-185.

Smith, V. H. 2003. Eutrophication of freshwater and coastal marine ecosystems. Environ. Sci. Pollut. Res. 10: 126-139.

Sneddon, L. U., and J. Yerbury. 2004. Differences in response to hypoxia in the three-spined stickleback from lotic and lentic localities: dominance and an anaerobic metabolite. J. Fish Biol. 64: 799-804.

Stefanelli, A. 1980. I neuroni di Mauthner degli Ittiopsidi. Valutazioni comparative orfologiche e funzionali. Lincei Mem. Sci. Fis. Mat. Nat. 16: 1-45.

Stierhoff, K. L., T. E. Targett, and K. Miller. 2006. Ecophysiological responses of juvenile summer and winter flounder to hypoxia: experimental and modeling analyses of effects on estuarine nursery quality. Mar. Ecol. Prog. Ser. 325: 255-266.

Suzue, T., G. B. Wu, and T. Furukawa. 1987. High susceptibility to hypoxia of afferent synaptic transmission in the goldfish sacculus. $\underline{J}$. Neurophysiol. 58: 1066-1079.

Szabo, T. M., S. A. Weiss, D. S. Faber, and T. Preuss. 2006. Representation of auditory signals in the M-cell: role of electrical synapses. $J$. Neurophysiol. 95: 2617-2629.

UNEP (United Nations Environment Programme) and UN-Habitat (United Nations Human Settlement Programme). 2005. Coastal area pollution: the role of cities. [Online]. Available: http://mirror.unhabitat.org /pmss/getElectronicVersion.asp?nr=2227\&alt=1 [2019, July 2].

Van Meter, K. J., P. Van Cappellen, and N. B. Basu. 2018. Legacy nitrogen may prevent achievement of water quality goals in the Gulf of Mexico. Science 360: 427-430.
Vaquer-Sunyer, R., and C. M. Duarte. 2008. Thresholds of hypoxia for marine biodiversity. Proc. Natl. Acad. Sci. U.S.A. 105: 15452-15457.

Wang, T., S. Lefevre, D. T. T. Huong, N. van Cong, and M. Bayley. 2009. The effects of hypoxia on growth and digestion. Fish Physiol. 27: 361-396.

Wannamaker, C. M., and J. A. Rice. 2000. Effects of hypoxia on movements and behavior of selected estuarine organisms from the southeastern United States. J. Exp. Mar. Biol. Ecol. 249: 145-163.

Webb, R. M. T., and F. Gómez-Gómez. 1998. Synoptic Survey of Water Quality and Bottom Sediments, San Juan Bay Estuary System, Puerto Rico, December 1994-July 1995. Water-Resources Investigations Report 97-4144. U.S. Geological Survey, Denver, CO.

Weis, J. S., L. Bergey, J. Reichmuth, and A. Candelmo. 2011. Living in a contaminated estuary: behavioral changes and ecological consequences for five species. BioScience 61: 375-385.

Wells, R. M. G. 2009. Blood-gas transport and hemoglobin function: adaptations for functional and environmental hypoxia. Fish Physiol. 27: 255-299.

Wolf, N. G., and D. L. Kramer. 1987. Use of cover and the need to breathe: the effects of hypoxia on vulnerability of dwarf gouramis to predatory snakeheads. Oecologia 73: 127-132.

Wu, R. S. 2002. Hypoxia: from molecular responses to ecosystem responses. Mar. Pollut. Bull. 45: 35-45.

Wu, R. S. 2009. Effects of hypoxia on fish reproduction and development. Fish Physiol. 27: 79-141.

Zhang, J., D. Gilbert, A. Gooday, L. Levin, S. W. A. Naqvi, J. J. Middelburg, M. Scranton, W. Ekau, A. Pena, B. Dewitte et al. 2010. Natural and human-induced hypoxia and consequences for coastal areas: synthesis and future development. Biogeosciences 7: 14431467.

Zottoli, S. J. 1977. Correlation of the startle reflex and Mauthner cell auditory responses in unrestrained goldfish. J. Exp. Biol. 66: 243-254.

Zottoli, S. J. 1978. Comparative morphology of the Mauthner cell in fish and amphibians. Pp. 13-45 in Neurobiology of the Mauthner Cell, D. S. Faber and H. Korn, eds. Raven Press, New York.

Zottoli, S. J. 1981. Electrophysiological and morphological characterization of the winter flounder Mauthner cell. J. Comp. Physiol. A Neuroethol. Sens. Neural Behav. Physiol. 143: 541-553.

Zottoli, S. J., A. P. Bentley, B. J. Prendergast, and H. I. Rieff. 1995. Comparative studies on the Mauthner cell of teleost fish in relation to sensory input. Brain Behav. Evol. 46: 151-164.

Zottoli, S. J., B. C. Newman, H. I. Rieff, and D. C. Winters. 1999. Decrease in occurrence of fast startle responses after selective Mauthner cell ablation in goldfish (Carassius auratus). J. Comp. Physiol. A Neuroethol. Sens. Neural Behav. Physiol. 184: 207-218.

Zottoli, S. J., T. W. Wong, M. A. Agostini, and J. R. Meyers. 2011. Axon cap morphology of the sea robin (Prionotus carolinus) Mauthner cell is correlated with the presence of "signature" field potentials and a C-type startle response. J. Comp. Neurol. 519: 1979-1998. 


\section{Appendix}

Table A1

Condado Lagoon water quality

\begin{tabular}{|c|c|c|c|c|c|}
\hline Name & Month-year & Temperature $\left({ }^{\circ} \mathrm{C}\right)$ & Dissolved oxygen (\%) & Latitude & Longitude \\
\hline Laguna del Condado 1 & Mar-15 & 27.53 & 101.20 & 18.457225 & -66.076954 \\
\hline Laguna del Condado 1 & Apr-15 & 27.80 & 90.20 & 18.457225 & -66.076954 \\
\hline Laguna del Condado 1 & May-15 & 28.12 & 97.30 & 18.457225 & -66.076954 \\
\hline Laguna del Condado 1 & Jun-15 & 32.22 & 92.40 & 18.457225 & -66.076954 \\
\hline Laguna del Condado 1 & Jul-15 & 29.73 & 94.10 & 18.457225 & -66.076954 \\
\hline Laguna del Condado 1 & Aug-15 & 32.90 & 117.00 & 18.457225 & -66.076954 \\
\hline Laguna del Condado 1 & Sep-15 & 32.52 & 81.20 & 18.457225 & -66.076954 \\
\hline Laguna del Condado 1 & Oct-15 & 30.65 & 42.80 & 18.457225 & -66.076954 \\
\hline Laguna del Condado 1 & Nov-15 & 29.32 & 75.30 & 18.457225 & -66.076954 \\
\hline Laguna del Condado 1 & Dec-15 & 28.74 & 55.50 & 18.457225 & -66.076954 \\
\hline Laguna del Condado 1 & Jan-16 & 28.59 & 69.70 & 18.457225 & -66.076954 \\
\hline Laguna del Condado 1 & Feb-16 & 26.83 & 72.60 & 18.457225 & -66.076954 \\
\hline
\end{tabular}

Data from https://atlas.estuario.org/calidad-de-agua/calidad-de-agua. Query used: Name = Laguna Condado 1, Year = 2015 and 2016.

Table A2

Hypoxic events in the San Juan Bay Estuary (2014-2016)

\begin{tabular}{|c|c|c|c|c|c|}
\hline Name & Month-year & Dissolved oxygen $\left(\mathrm{mg} \mathrm{L}^{-1}\right)$ & Dissolved oxygen (\%) & Latitude & Longitude \\
\hline Laguna del Condado 1 & Oct-15 & 2.52 & 42.80 & 18.457225 & -66.076954 \\
\hline Laguna del Condado 1 & Aug-16 & 0.00 & 0.00 & 18.457225 & -66.076954 \\
\hline Laguna Los Corozos & Jan-15 & 3.33 & 45.80 & 18.441579 & -66.038588 \\
\hline Laguna Los Corozos & Apr-15 & 2.11 & 35.90 & 18.441579 & -66.038588 \\
\hline Laguna San José 1 & Feb-14 & 2.28 & 31.70 & 18.428583 & -66.035523 \\
\hline Laguna San José 1 & Mar-14 & 1.62 & 22.50 & 18.428583 & -66.035523 \\
\hline Laguna San José 1 & Apr-15 & 2.50 & 2.50 & 18.428583 & -66.035523 \\
\hline Laguna San José 1 & Nov-15 & 1.7 & 14.70 & 18.428583 & -66.035523 \\
\hline Laguna San José 1 & May-16 & 2.32 & 34.70 & 18.428583 & -66.035523 \\
\hline Laguna San José 1 & Oct-16 & 1.3 & 22.60 & 18.428583 & -66.035523 \\
\hline Laguna San José 2 & May-14 & 8.61 & 48.70 & 18.424755 & -66.020036 \\
\hline Laguna San José 2 & Apr-15 & 2.91 & 37.30 & 18.424755 & -66.020036 \\
\hline Laguna San José 2 & May-15 & 2.29 & 27.00 & 18.424755 & -66.020036 \\
\hline Laguna Torrecilla 1 & Jan-16 & & 28.80 & 18.457653 & -65.992482 \\
\hline Laguna Torrecilla 1 & Jul-16 & 4.95 & 40.20 & 18.457653 & -65.992482 \\
\hline Laguna Torrecilla 1 & Dec-16 & 4.97 & 24.60 & 18.457653 & -65.992482 \\
\hline Laguna Torrecilla 2 & Oct-15 & 1.37 & 19.90 & 18.443649 & -65.979654 \\
\hline Laguna Torrecilla 3 & Oct-14 & 2.03 & 29.90 & 18.436139 & -65.969095 \\
\hline Laguna Torrecilla 3 & Nov-14 & 2.30 & 38.60 & 18.436139 & -65.969095 \\
\hline Laguna Torrecilla 3 & Jan-15 & 3.24 & 49.60 & 18.436139 & -65.969095 \\
\hline Laguna Torrecilla 3 & Mar-15 & 2.28 & 34.40 & 18.436139 & -65.969095 \\
\hline Laguna Torrecilla 3 & Apr-15 & & 5.61 & 18.436139 & -65.969095 \\
\hline Laguna Torrecilla 3 & Aug-15 & 0.47 & 30.40 & 18.436139 & -65.969095 \\
\hline Laguna Torrecilla 3 & Sep-15 & 1.55 & 21.70 & 18.436139 & -65.969095 \\
\hline Laguna Torrecilla 3 & Oct-15 & 0.27 & 5.90 & 18.436139 & -65.969095 \\
\hline Laguna Torrecilla 3 & Nov-15 & 1.05 & 13.30 & 18.436139 & -65.969095 \\
\hline Laguna Torrecilla 3 & Jan-16 & 2.21 & 7.70 & 18.436139 & -65.969095 \\
\hline Laguna Torrecilla 3 & Feb-16 & 1.08 & 14.80 & 18.436139 & -65.969095 \\
\hline Laguna Torrecilla 3 & Apr-16 & 1.05 & 17.50 & 18.436139 & -65.969095 \\
\hline Laguna Torrecilla 3 & Sep-16 & 2.36 & 36.90 & 18.436139 & -65.969095 \\
\hline Laguna Torrecilla 3 & Oct-16 & 0.6 & 15.10 & 18.436139 & -65.969095 \\
\hline Laguna Torrecilla 3 & Nov-16 & 0.79 & 10.10 & 18.436139 & -65.969095 \\
\hline Laguna Torrecilla 3 & Dec-16 & 2.55 & 31.10 & 18.436139 & -65.969095 \\
\hline
\end{tabular}

Data from https://atlas.estuario.org/calidad-de-agua/calidad-de-agua. Query used: Dissolved Oxygen $=0-2.5 \mathrm{mg} / \mathrm{L}$ and $0 \%-40 \%$. 